\title{
Assessment of pollutant dispersion from rooftop stacks: ASHRAE, ADMS and wind tunnel simulation
}

\author{
B. Hajra ${ }^{\mathrm{a}}$, T. Stathopoulos ${ }^{\mathrm{a}^{*}}$, A. Bahloul ${ }^{\mathrm{b}}$ \\ a Department of Building, Civil and Environmental Engineering, Concordia University, \\ Montreal, Canada \\ ${ }^{b}$ Institut de recherche Robert-Sauvé en santé et en sécurité du travail, Montreal, Canada
}

\begin{abstract}
The prediction of downwind concentration of effluents from stack located on top of buildings is important. Most current dispersion models assess the pollutant concentration at distances away from the building. It is important to study pollutant dispersion within the recirculation zone of the building, since studies have shown that effluents released from rooftop stacks have a tendency to re-enter the building through intakes located on the roof. These effects get more pronounced with the influence of RoofTop Structures (RTS). This paper presents a comparative study of the Atmospheric Dispersion Modelling System (ADMS), American Society of Heating, Refrigerating and Air Conditioning Engineers (ASHRAE 2003 and 2007 versions) and wind tunnel results. Four different cases involving a low-rise and high-rise building for stack heights $\left(\mathrm{h}_{\mathrm{s}}\right)$ ranging from $1 \mathrm{~m}$ to $7 \mathrm{~m}$, exhaust momentum ratios $(\mathrm{M})$ ranging from 1 to 5 and wind direction $(\theta)$ of $0^{\circ}$ and $45^{\circ}$, have been studied for neutral atmospheric stability conditions. In this regard the effect of RTS has also been examined by using wind tunnel, ADMS and ASHRAE models. ADMS yields higher dilutions near the stack at $\theta=0^{\circ}$ and cannot model the effect of RTS. Wind tunnel data compare well with ASHRAE 2003 at M = 5 for the low-rise building, but generally predict higher dilutions for the high-rise building. ASHRAE 2003 predicts lower dilutions than ADMS for the high-rise building, while ASHRAE 2007 yields very low dilutions for all cases, suggesting a need to re-assess its suitability for practical design.
\end{abstract}

Keywords: Building; Dilution; Dispersion; Rooftop stack; Wind tunnel

*Corresponding author.Tel.001-514-848-2424; ext: 3186

E-mail address: statho@cbs-engr.concordia.ca 


\section{Introduction}

Wind flow and turbulence in the vicinity of buildings have a high impact on pollutant dispersion from nearby stacks and increases the possibility of high pollutant concentration at air intakes [1]. The recirculation zone formed downwind of the stack encourages effluents to re-enter the building through openings located downwind of a stack. The re-entrainment phenomenon involves plume downwash and formation of recirculation cavity, as explained previously [2].

Short range atmospheric dispersion models were presented by Pasquill and Gifford in 1961 [3, 4]. Currently, there are various computational models which use mathematical and numerical techniques to simulate the atmospheric and meteorological conditions for determining effluent dispersion from stacks located on buildings [5]. One of the most widely used models is the Atmospheric Dispersion Modelling System (ADMS), developed in England, which is also endorsed by the United States Environmental Protection Agency. In a recent study to assess the quality and applicability of various dispersion models for near-field dispersion, ADMS was the only model producing good comparisons with ASHRAE and wind tunnel results [6]. Other models such as CALPUFF, SCREEN and AFTOX did not provide promising results for the assessment of dispersion of pollutants near buildings.

In the present study, ADMS has been used to model several cases involving a lowrise and a high-rise building for stack heights $\left(h_{s}\right)$ ranging from $1 \mathrm{~m}$ to $7 \mathrm{~m}$ and exhaust momentum ratios $(\mathrm{M})$ varying from 1 to 5 , to evaluate the concentration of effluents on top of a flat roof. A few experimental results obtained from the boundary layer wind tunnel for a wind direction of $45^{\circ}$ have been compared to those produced by ADMS model. Furthermore, the influence of RoofTop Structure (RTS) has also been studied since earlier studies have shown the ill effects of rooftop obstacles in increasing pollutant concentrations around the building [6].

ASHRAE provides a geometric stack design method for estimating the minimum stack height to avoid plume entrainment in the flow recirculation zones of a building and its rooftop structures. It also gives formulations for determining the receptor concentrations as dilutions $[7,8]$. All results have been expressed as normalised dilutions 
in order to make them comparable with wind tunnel data and ADMS. Both 2003 and 2007 ASHRAE versions have been used for all cases involving wind angle of $0^{\circ}$.

Wind tunnel experimentation was carried out at the boundary layer wind tunnel of the Building Aerodynamics laboratory at Concordia University. While performing the tests certain assumptions have also been used which are described in subsequent sections of the paper.

Section 2 of this paper describes the formulations of ASHRAE, followed by a brief description of ADMS model in section 3. The wind tunnel experimental set up and the various cases examined have been discussed in sections 4 and 5 respectively. Section 6 presents the results and discussion followed by conclusions in section 7. An appendix describing the calculations of ASHRAE 2003 and ASHRAE 2007 has also been included.

\section{ASHRAE 2007}

The American Society of Heating, Refrigerating and Air Conditioning Engineers (ASHRAE) has developed standards for designers dealing with the design and maintenance of indoor environment (http://www.ashrae.org). ASHRAE Applications Handbook, Chapter 44, 2007, gives certain guidelines that can be used for determining the stack height and rooftop dilutions [8].

A geometric stack design method for estimating the minimum stack height to avoid plume entrainment in the flow recirculation zones of a building and its RTS is presented in Figure 1. Dimensions of the recirculation zones are expressed in terms of the scaling length, $\mathrm{R}$, which is defined as:

$$
R=B_{s}^{0.67} B_{L}^{0.33}
$$

where:

$\mathrm{B}_{\mathrm{s}}$ is the smaller of upwind building height or width and $\mathrm{B}_{\mathrm{L}}$ is the larger of these dimensions (m).

The dimensions of flow re-circulation zones that form on the building and RTS are:

$$
\begin{aligned}
& h_{\text {Top }}=0.22 R \\
& X_{c}=0.5 R \\
& L_{c}=0.9 R
\end{aligned}
$$


where: $\mathrm{h}_{\text {Top }}$ is the maximum height of the roof recirculation zone $(\mathrm{m})$,

$\mathrm{X}_{\mathrm{c}}$ is the distance from the leading edge to $\mathrm{H}_{\mathrm{c}}(\mathrm{m})$,

$\mathrm{L}_{\mathrm{c}}$ is the length of the roof recirculation zone $(\mathrm{m})$

and $L_{r}$ is the length of the building wake zone $(\mathrm{m})$.

These formulations remain unchanged from ASHRAE 2003 and are useful in estimating the minimum stack height, which can be used to just avoid the recirculation zone. The design method assumes that the boundary of the high turbulence region is defined by a line with a slope of 10:1 extending from the top of the leading edge separation bubble. The location of the plume relative to the recirculation zones is determined by taking into account plume rise due to exhaust momentum and assuming a conical plume with a slope of 5:1, as shown in Figure 1. However, this method cannot be used to find the dilution at a given receptor, which is important for assessing the suitability of the location of the intake structure.

The effective height of the plume above the roof or RTS is:

$h=h_{s}+h_{r}-h_{d}$

where:

$\mathrm{h}_{\mathrm{s}}$ is stack height $(\mathrm{m})$,

$\mathrm{h}_{\mathrm{r}}$ is plume rise $(\mathrm{m})$ and

$h_{d}$ is the reduction in plume height due to entrainment into the stack wake during periods of strong winds $(\mathrm{m})$.

Plume rise, which is assumed to occur instantaneously, is calculated using the formula of Briggs [9]:

$h_{r}=3 \beta d_{e}\left(V_{e} / U_{H}\right)$

where: $d_{\mathrm{e}}$ is the stack diameter $(\mathrm{m})$,

$\mathrm{V}_{\mathrm{e}}$ is the exhaust velocity $(\mathrm{m} / \mathrm{s})$,

$\mathrm{U}_{\mathrm{H}}$ is the wind speed at building height $(\mathrm{m} / \mathrm{s})$

and $\beta$ is the stack capping factor. The value of $\beta$ is 1 for uncapped stacks and 0 for capped stacks.

To account for the stack downwash caused by low exit velocities, when $\mathrm{V}_{\mathrm{e}} / \mathrm{U}_{\mathrm{H}}<3.0$, 
Wilson et al. [10] recommended a stack wake downwash adjustment $h_{d}$, which is defined as:

$h_{d}=d_{e}\left(3-\beta V_{e} / U_{H}\right)$

For $\mathrm{V}_{\mathrm{e}} / \mathrm{U}_{\mathrm{H}}>3.0$ there is no stack downwash $\left(\mathrm{h}_{\mathrm{d}}=0\right)$.

Dilution at roof level in a Gaussian plume emitted at the final rise plume height of $\mathrm{h}$ is:

$D_{r}=4\left(U_{H} / V_{e}\right)\left(\sigma_{y} / d_{e}\right)\left(\sigma_{z} / d_{e}\right) \exp \left(\zeta^{2} / 2 \sigma_{z}^{2}\right)$

where: $\zeta=\mathrm{h}-\mathrm{h}_{\mathrm{Top}}$

$$
=0 \text { if } \mathrm{h}<\mathrm{h}_{\mathrm{Top}}
$$

$D_{r}=\mathrm{C}_{\mathrm{e}} / \mathrm{C}_{\mathrm{r}}$

$\mathrm{C}_{\mathrm{e}}=$ contaminant mass concentration in exhaust, $\mathrm{kg} / \mathrm{m}^{3}$

$\mathrm{C}_{\mathrm{r}}=$ contaminant mass concentration in receptor, $\mathrm{kg} / \mathrm{m}^{3}$

$\mathrm{h}_{\text {Top }}$ is defined as the height of the highest active obstacle or recirculation zone on a rooftop between stack and intake. For a flat roof with no RTS, $\mathrm{h}_{\mathrm{Top}}$ is calculated from equation 2. In the presence of an RTS, $\mathrm{h}_{\mathrm{Top}}$ has to be calculated by considering the dimensions of the RTS.

$\zeta$ is the vertical separation between ' $h$ ' and $\mathrm{h}_{\text {Top. }}$.

The plume equations are as follows:

$\sigma_{y} / d_{e}=0.071\left(t_{\text {avg }} / 2\right)^{0.2}\left(X / d_{e}\right)+\sigma_{o} / d_{e}$

$\sigma_{z} / d_{e}=0.071\left(X / d_{e}\right)+\sigma_{o} / d_{e}$

The dependence of initial spread $\sigma_{o}$ on exit velocity to wind speed ratio $V_{e} / U_{H}$ is

$\sigma_{o} / d_{e}=\left[0.125 \beta\left(V_{e} / U_{H}\right)+0.911 \beta\left(V_{e} / U_{H}\right)^{2}+0.25\right]^{0.5}$

where:

$t_{a v g}$ is the concentration averaging time in minutes,

$\mathrm{X}$ is the distance downwind from the stack $(\mathrm{m})$,

$\sigma_{\mathrm{y}}$ and $\sigma_{\mathrm{z}}$ are standard deviations of the plume $(\mathrm{m})$.

$\sigma_{o}$ is the initial source size that accounts for stack diameter and for dilution jet entrainment during plume rise $(\mathrm{m})$. A plume which is represented in three dimensions by Gaussian equations will have standard deviations $\sigma_{y}$ and $\sigma_{z}$ along ' $y$ ' and ' $z$ ' axes respectively, at a given longitudinal distance ' $x$ ', as shown in Figure 2. The values of $\sigma_{y}$ 
and $\sigma_{z}$ are calculated from equations 9 and 10 respectively at a given receptor distance, exhaust momentum ratio, stack diameter and averaging time.

However, ASHRAE 2003 gives the following formulae to calculate the dilution:

$D_{r}=4\left(U_{H} / V_{e}\right)\left(\sigma_{y} / d_{e}\right)\left(\sigma_{z} / d_{e}\right) \exp \left(h^{2} / 2 \sigma_{z}^{2}\right)$

where " $h$ " is given by equation 5 .

ASHRAE 2003 uses the concept of the smallest plume height $\left(\mathrm{h}_{\text {small }}\right)$. For flat roof without RTS, the value of $h_{\text {small }}$ is evaluated by drawing a triangle with edges at 5:1 from the centre (similar to the one shown in Figure 1) such that the side of the triangle just crosses the building wake recirculation region (shown as ' $\mathrm{L}_{\mathrm{r}}$ ' in Figure 1). ASHRAE 2003 states that if $\mathrm{h}<\mathrm{h}_{\text {small, }}$, the dilutions must be calculated by considering a flush vent

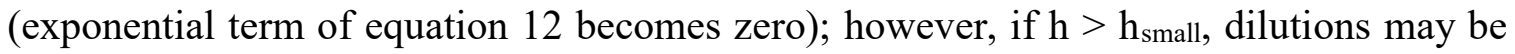
estimated by equation 12 . The value of ' $h$ ' is always calculated from equation 5 . The physical interpretation is that when the value of ' $h$ ', which includes stack height, plume rise and downwash, is less than the smallest possible plume height, pollutant dispersion is reduced resulting in lower dilutions. For a given building, if the RTS is located downstream of the stack the value of $h_{\text {small }}$ will be higher. However, for an RTS placed upstream of the stack the value of $h_{\text {small }}$ remains unchanged as compared to building with flat roof. In ASHRAE 2007 the concept of smallest plume height has been replaced by $\mathrm{h}_{\text {Top, }}$ which has been defined earlier. Again, if $\mathrm{h}<\mathrm{h}_{\mathrm{Top}}$, calculations must be done assuming a flush vent, in which case the exponential term from equation 8 becomes zero, i.e. equations 8 and 12 become identical.

Formulations for determining the normalised dilution from the concentrations are also available in ASHRAE 2007. However, since ADMS gives results in concentrations rather than dilutions, the following formulation by Wilson et al. [11, 12] has been used for evaluating normalised dilutions from concentrations:

$\mathrm{D}_{\text {normalised }}=\left(\mathrm{D}_{\mathrm{r}} \mathrm{Q}\right) /\left(\mathrm{U}_{\mathrm{H}} \mathrm{H}^{2}\right)$

where:

$\mathrm{Q}=\pi \mathrm{d}_{\mathrm{e}}^{2} \mathrm{~V}_{\mathrm{e}} / 4$ is the volumetric flow-rate $\left(\mathrm{m}^{3} / \mathrm{s}\right)$

Normalised dilutions are useful in scaling down the quantities to mere ratios of concentrations so that they can be compared to other models. 


\section{ADMS}

The Atmospheric Dispersion Modelling System (ADMS) is a widely used "Gaussian plume model". It is an advanced dispersion model developed in England for calculating effluent concentrations emitted either continuously from point, line, volume and area sources, or discretely from point sources. This model simulates a wide range of buoyant and passive releases to the atmosphere assuming the boundary layer structure to be based on the Monin Obukhov length and the boundary layer height. The model also assumes concentration distributions to be Gaussian in neutral and stable conditions, but the vertical distribution to be non-Gaussian in convective conditions to account for the skewed structure of the vertical component of the turbulence [13].

In this study ADMS 3, version 3.2 has been used. This requires the mass flow rate of the pollutant emitted, meteorological details, building configurations, stack and receptor locations and topographic details, as input variables. The output can be viewed as concentrations at specific locations or as contour plots, as desired by the user. For a neutral and stable boundary the concentration distribution is given by:

$$
C=\left(Q_{e} / 2 \pi \sigma_{y} \sigma_{z} U(z)\right) e^{\left(-y^{2} / 2 \sigma_{y}{ }^{2}\right)}\left\{\begin{array}{l}
e^{-\left(z-z_{s}\right)^{2} / 2 \sigma_{z}{ }^{2}}+e^{-\left(z+z_{s}\right)^{2} / 2 \sigma_{z}{ }^{2}}+e^{-\left(z+2 h^{*}-z_{s}\right)^{2} / 2 \sigma_{z}{ }^{2}}+ \\
e^{-\left(z-2 h^{*}+z_{s}\right)^{2} / 2 \sigma_{z}{ }^{2}}+e^{-\left(z-2 h^{*}-z_{s}\right)^{2} / 2 \sigma_{z}{ }^{2}}
\end{array}\right\}
$$

where:

$\sigma_{\mathrm{y}}$ and $\sigma_{\mathrm{z}}$ are plume dimensions along the two lateral directions: "y" and " $\mathrm{z}$ " $(\mathrm{m})$,

$\mathrm{U}(\mathrm{z})$ is the wind velocity $(\mathrm{m} / \mathrm{s})$ at height ' $\mathrm{z}$ ',

$\mathrm{Q}_{\mathrm{e}}$ is the mass flow rate $(\mathrm{kg} / \mathrm{s})$,

$\mathrm{Z}_{\mathrm{S}}$ is the height of the source $(\mathrm{m})$,

$\mathrm{h}^{*}$ is the atmospheric boundary layer height (m)

In neutral atmospheric conditions the non buoyant part of the plume does not penetrate the top of the boundary layer, which makes the effluents reflect downwards. ADMS assumes that vertical concentration variations away from the source to be negligible [13]. 


\section{Wind tunnel experimental setup and simulation conditions}

The wind tunnel experiments were carried out in the open circuit boundary layer wind tunnel laboratory at Concordia University. It is $1.8 \mathrm{~m}$ by $1.8 \mathrm{~m}$ in section and $12.2 \mathrm{~m}$ in length. The building models tested were made of timber on a 1:200 scale. The velocity and turbulence intensity profiles are shown in Figure 3. A thick atmospheric boundary layer (power law exponent of 0.3) was simulated using vortex generators and spires at the entrance of the test section and panels with dense roughness elements. The depth of the boundary layer (gradient height) was approximately $90 \mathrm{~cm}$. The flow in the wind tunnel was turbulent with stable time-averaged flow conditions throughout the tests. The roof of the tunnel was adjusted to ensure that the longitudinal static pressure gradient was negligible. The front view section of the wind tunnel is shown in Figure 4.

A tracer gas consisting of a mixture of Sulphur hexafluoride $\left(\mathrm{SF}_{6}\right)$ and Nitrogen was released from stack heights ranging from $1 \mathrm{~m}$ to $7 \mathrm{~m}$ in full scale and $\mathrm{M}$ varying from 1 through 5 . Since the highest stack in the study was only $3.5 \mathrm{~cm}$ (representing a $7 \mathrm{~m}$ tall stack in full scale), the roof height of the wind tunnel is sufficient for the development of the plume rise without affecting the vertical and horizontal spread of the plume. The $\mathrm{SF}_{6}$ samples were collected by a multi-syringe sampler connected to each receptor via tubing; hence the possibility of any background concentration affecting the results is reduced. The syringes were organised in a syringe sampler having a mechanism by which the syringes can be fixed to the instrument so that they could suck the air samples within one minute, once the wind tunnel and release of gas are stabilised (after about 4 minutes). Any background concentration of $\mathrm{SF}_{6}$ in the wind tunnel was removed quickly by the ventilation system of the laboratory. A Gas Chromatograph (GC) was used to assess the gas concentrations that were collected using the syringe samplers. Deviations in concentration measurements were usually within $\pm 20 \%$. This is generally considered to be accurate for tracer measurements in wind tunnel [6].

According to Snyder [14] while modelling non-buoyant plume exhaust the following criteria should be satisfied for adequate simulation conditions:

- Geometric similarity

- Building Reynolds Number $>11000$

- $\quad$ Stack Reynolds Number $>2000$ 
- Similarity of wind tunnel flow with atmospheric surface layer

- Equivalent stack momentum ratio.

For additional details, the reader may consult reference [15]. In short, the velocity at building height was measured to be $5.4 \mathrm{~m} / \mathrm{s}$ in the wind tunnel. Normalised dilutions were calculated from equation 13 to make the results obtained from ASHRAE and ADMS models comparable. Since it was assumed that the buildings considered in all cases were in an urban terrain, which corresponds to terrain category 2 [16], the previously mentioned power law exponent of 0.3 was adequate to determine the velocity at building height $\left(\mathrm{U}_{\mathrm{H}}\right)$. The model value of the longitudinal integral scale was $0.4 \mathrm{~m}$, which corresponds to a full-scale value of $80 \mathrm{~m}$. The model roughness length of the upstream exposure was $3.3 \mathrm{~mm}$, which corresponds to a full-scale roughness length of $0.66 \mathrm{~m}$. When full-scale averaging time increases, mean concentration decreases due to plume meander caused by turbulence and fluctuations in wind direction.

Wind tunnels can only model plume meander due to small-scale turbulence since the walls restrict the flow in the lateral direction. When the source and receptor locations lie in the same recirculation zone, as in the present study, the effects of averaging time are expected to diminish. In such cases, ASHRAE suggests that dilution values obtained up to an averaging time of 2 minutes in the wind tunnel correspond to full-scale averaging time up to one hour [7, 8]. As already mentioned, the averaging time for collection of the samples in the experiments carried out in the wind tunnel was only one minute, since the instrument is capable of measuring samples at an averaging time of one minute. This is not expected to affect the accuracy of the measurements, as discussed further in Stathopoulos et al. [6]. The Reynolds number for the building model was found to be approximately 20,000, which is larger than 11,000, while the stack Reynolds number was nearly 1800 , somewhat less than 2000 . This did not seem to affect the measurements see Stathopoulos et al. [17].

\section{The cases examined}

Four different cases were considered in the experiments. These include a high-rise building with wind angle at $0^{\circ}$ (normal to the building face) and a low-rise building, without RTS, with wind angles at $0^{\circ}$ and $45^{\circ}$ respectively. Additionally, the effect of RTS 
was also examined for the low-rise building at the critical wind angle of $0^{\circ}$. Results for each of these cases are presented and discussed in the following section. A diagrammatic representation of the high-rise and low-rise building with flat roof showing the stack and receptor locations is shown in Figure 5 (a) and Figure 5 (b) respectively. Figure 6 shows the stack, receptor and RTS location of the low-rise building. The dimensions of each building and RTS are presented in Table 1.

Table 1. Dimensions of building and RTS.

\begin{tabular}{|l|c|c|c|}
\hline Structure & Height $(\mathrm{m})$ & Width $(\mathrm{m})$ & Breadth $(\mathrm{m})$ \\
\hline Low-rise building & 15 & 50 & 50 \\
\hline High-rise building & 60 & 50 & 50 \\
\hline RTS & 4 & 30 & 8 \\
\hline
\end{tabular}

NB: Width represents the dimension perpendicular to wind at $0^{\circ}$.

Wind was considered perpendicular to the building face. For all cases the receptors were $5 \mathrm{~m}$ apart, downwind the stack and the stack location was $20 \mathrm{~m}$ from the upwind edge of the building and $25 \mathrm{~m}$ from the lateral edges. The RTS was centrally placed upwind of the stack and $6 \mathrm{~m}$ away from the upwind edge of the building. The various cases examined in this study are presented in Table 2.

Table 2. Cases examined.

\begin{tabular}{|l|c|c|c|}
\hline \multicolumn{1}{|c|}{ Case } & $\theta$ & $\mathrm{M}$ & $\mathrm{h}_{\mathrm{s}}(\mathrm{m})$ \\
\hline $\begin{array}{l}\text { High-rise building } \\
\text { with flat roof }\end{array}$ & $0^{\circ}$ & $1,2,3,5$ & $1,3,5,7$ \\
\hline $\begin{array}{l}\text { Low-rise building } \\
\text { with flat roof }\end{array}$ & $0^{\circ}$ and $45^{\circ}$ & $1,2,3,5$ & $1,3,5,7$ \\
\hline $\begin{array}{l}\text { Low-rise building } \\
\text { with RTS }\end{array}$ & $0^{\circ}$ & $1,2,3,5$ & $1,3,5,7$ \\
\hline
\end{tabular}

\section{Results and discussion}

Prior to presenting and discussing the results of this study, an attempt was made to compare the wind tunnel data with some previous results carried out by other investigators. In this regard, Figure 7 shows comparisons between data from present study and wind tunnel data from Schulman and Scire [18] and Lowery and Jacko [19] in terms of normalised dilutions. In spite of differences in the experimental conditions - see details in Table 3 - results have good similarity. In particular, the agreement between the normalised dilutions measured in the present study with those reported in reference 18 is excellent, particularly at points further away from the stack. It should be noted that 
Table 3 Experimental parameters used for the present and previous studies.

\begin{tabular}{|l|l|l|l|}
\hline Experimental parameters & Present study & $\begin{array}{l}\text { Schulman and } \\
\text { Scire.[18] }\end{array}$ & $\begin{array}{l}\text { Lowery and } \\
\text { Jacko.[19] }\end{array}$ \\
\hline Model scale & $1: 200$ & $1: 100$ & $1: 120$ \\
\hline Wind speed at building height (m/s) & 5.4 & 1.37 & 3.4 \\
\hline Upstream terrain & Urban & Suburban & Suburban \\
\hline Power law exponent & 0.30 & 0.20 & 0.23 \\
\hline Stack diameter (m) & 0.6 & 0.75 & 0.75 \\
\hline Building height (m) & 15 & 15 & 7 \\
\hline Building width (m) & 50 & 75 & 90 \\
\hline Building breadth (m) & 50 & 75 & 90 \\
\hline
\end{tabular}

NB: Width refers to building dimension perpendicular to wind direction at $0^{\circ}$.

building heights and stack heights are similar but the building is larger, the exposure is suburban, as opposed to urban in the present study. Dilutions from reference 19 are higher but the building is much larger, its height is about half, in addition to the upstream terrain being smoother as well. Regardless of these differences, the overall comparisons and trends of data are encouraging.

The results and discussion presented in this section have been divided into four subsections, each of which discusses one particular case in detail. Totally, about 64 different cases were studied of which only ten are presented in Figures 8 through 12. Figures 8 through 11 show results for a $1 \mathrm{~m}$ high stack at $\mathrm{M}=3$ and $\mathrm{M}=5$, while Figure 12 compares different models for $h_{s}=1 \mathrm{~m}$ and $h_{s}=5 \mathrm{~m}$ at $\mathrm{M}=1$.

\subsection{High-rise building with wind angle at $0^{\circ}$}

The downwind concentration of effluents in the form of normalised dilutions has been presented for a high-rise building with $1 \mathrm{~m}$ stack at $\mathrm{M}=3$, in Figure 8 (a). Dilutions found in the wind tunnel are 100 times higher than those evaluated by ASHRAE (2003 and 2007) at all receptors by using equations 12 and 8, respectively. The differences arise from the exponential term of each equation. The method employed in estimating the value of " $h$ " in ASHRAE 2003 (" $\zeta "$ in ASHRAE 2007) is different, as explained further. Wind tunnel and ADMS compare well only within the first $10 \mathrm{~m}$ from the stack. The maximum deviation between the two is observed at $30 \mathrm{~m}$ from the stack, where ADMS generates 10 times lower dilutions than wind tunnel. At distances away from the source 
stack generated turbulence reduces which impacts the effluent concentrations on rooftops. ADMS does not include this feature for estimating concentrations at a rooftop receptor [6]. ASHRAE 2003 and 2007 predict comparable dilutions, for this case.

Figure 8 (b) presents comparisons between ASHRAE (2003 and 2007), ADMS and wind tunnel data for the high-rise building with stack height of $1 \mathrm{~m}$ at a higher value of $\mathrm{M}$ $(\mathrm{M}=5)$. Wind tunnel data predicts 100 times higher dilutions compared to ASHRAE (2003 and 2007). ADMS generates higher dilutions than wind tunnel within $20 \mathrm{~m}$ downwind of stack, but compare better thereafter. ASHRAE 2003 and 2007 predict comparable dilutions at all downwind receptors.

Usually, an increase in height results in reduced turbulence within the boundary layer, although "wave motions" may cause increased turbulence at the top of the boundary layer [13]. The effect of such "wave motions" is not considered by ADMS leading to reduced concentrations (higher dilutions) immediately downwind of stack. The results indicate that ADMS predicts high dilutions, while ASHRAE yields very conservative results for the high-rise building.

\subsection{Low-rise building with wind angle at $0^{\circ}$}

Figure 9 (a) presents comparisons between ASHRAE (2003 and 2007 versions), ADMS and wind tunnel for the low-rise building with stack of $1 \mathrm{~m}$ at $M=3$. It is observed that wind tunnel data predicts higher dilutions than ASHRAE (2003 and 2007), but generates lower dilutions than ADMS. The dilutions predicted by ASHRAE 2003 and 2007 are comparable. ADMS continues to predict higher dilutions at all points compared to all other models.

The results obtained from ADMS, ASHRAE (2003 and 2007) and the wind tunnel are presented for the low-rise building with stack height of $1 \mathrm{~m}$ at higher exhaust momentum $(M=5)$, in Figure $9(\mathrm{~b})$. Details of ASHRAE value calculations are provided in the Appendix. The results indicate that wind tunnel data predict higher dilutions than ASHRAE 2007, but generate lower dilutions than ASHRAE 2003 at all points downwind of the stack. ASHRAE 2003 predicts higher dilutions than ASHRAE 2007, but generally predicts lower dilutions than ADMS at all receptors. ASHRAE 2007 predicts very low 
dilutions, compared to all models at all points, yielding very conservative results. ADMS predicts very high dilutions compared to all models at all receptors.

\subsection{Low-rise building with wind angle at $45^{\circ}$}

Figure 10 (a) presents comparisons between ADMS and wind tunnel for the low-rise building with $1 \mathrm{~m}$ stack at $\mathrm{M}=3$ and $\theta=45^{\circ}$. It is necessary to perform this study since most models including ASHRAE always consider the maximum concentration at the plume centre line for $\theta=0^{\circ}$ and do not provide any formulations for change in wind angle. It must also be noted that the receptors in the experiment are also located at 45 degrees to the horizontal unlike the previous case, where the receptors lie in the same straight line as the wind direction. Validation of ADMS has been carried out against wind tunnel data previously [20] but studies involving change in wind direction have not been carried out so far, hence this case seeks special attention. ADMS and wind tunnel results compare well for almost all points, except within $10 \mathrm{~m}$ downwind of stack, where they deviate by about 10 times. Such deviations might be attributed to the effect of counterrotating conical vortices formed at the edge of the building [16], due to which pollutants released from rooftop stacks are brought down to the surface of the roof leading to low dilution immediately downwind of stack as estimated by wind tunnel measurements; such effects are not taken into account by ADMS.

Figure 10 (b) shows comparisons between ADMS and wind tunnel for the low-rise building for a $1 \mathrm{~m}$ stack at $\mathrm{M}=5$. It is observed that there is good agreement between the two models at almost all points beyond $3 \mathrm{~m}$ downwind of stack. The small discrepancy in data within the first $3 \mathrm{~m}$ can be attributed to the turbulence present immediately downwind of stack, which is not taken into account by ADMS model [6]. Overall, ADMS produces very good dilutions and this may be attributed to the higher value of $\mathrm{M}$, which generally yields a higher plume rise with no exhaust material trapped within the above-mentioned conical vortices.

\subsection{Low-rise building with RTS}

Figure 11 (a) presents comparisons between ASHRAE, ADMS and wind tunnel data for a stack of $1 \mathrm{~m}$ at $\mathrm{M}=3$. It should be mentioned that ADMS does not model the 
effects of RTS. Therefore, for the sake of completeness the results for low-rise building with stack height of $1 \mathrm{~m}$ without RTS, obtained from ADMS has been included in the figure. Wind tunnel provides lower dilutions than ASHRAE 2003 and ADMS but generates higher dilutions than ASHRAE 2007. ASHRAE 2003 and ADMS compare well within the first $15 \mathrm{~m}$ from the stack, but deviate thereafter. ASHRAE 2003 also predicts higher dilutions than ASHRAE 2007 at all points. Significant differences are observed for a $1 \mathrm{~m}$ high stack at $\mathrm{M}=5$, as depicted in Figure 11 (b). Although ASHRAE 2003 and wind tunnel data compare well for some points, ADMS predicts almost 10 times higher dilutions than wind tunnel. However, ASHRAE 2007 predicts very low dilutions, yielding very conservative results. This is not surprising because the effect of RTS has been studied only recently (see reference [6]) and results have not yet been considered by ASHRAE and other models.

\subsection{Effect of stack height}

Figure 12 (a) presents normalised dilutions for downwind receptors for a high-rise building for $\mathrm{h}_{\mathrm{s}}=1 \mathrm{~m}$ and $\mathrm{h}_{\mathrm{s}}=5 \mathrm{~m}$ obtained from the wind tunnel, ASHRAE 2003, ASHRAE 2007 and ADMS at M = 1. Results show that ASHRAE 2003 and ASHRAE 2007 predict lower dilutions than those from the wind tunnel irrespective of stack height. However, an increase in stack height should enhance plume rise leading to greater dispersion and marginal increase in dilutions. ADMS predicts much lower dilutions than the wind tunnel for $h_{s}=1 \mathrm{~m}$. Interestingly enough, at $h_{s}=5 \mathrm{~m}$, ADMS predicts higher dilutions than the wind tunnel within the first $10 \mathrm{~m}$ downwind of stack, but at distances closer to the downwind edge the situation is reversed. Although dilutions from wind tunnel data for $h_{s}=1 \mathrm{~m}$ are lower than those for $h_{s}=5 \mathrm{~m}$ immediately downwind of stack due to downwash, comparable dilutions were obtained beyond $10 \mathrm{~m}$ downwind of stack.

Significant differences are observed for a low-rise building as depicted in Figure 12 (b). Both versions of ASHRAE predict lower dilutions than those of the wind tunnel for all stack heights. At $h_{s}=1 \mathrm{~m}$, ADMS predicts lower dilutions than the wind tunnel within the first $8 \mathrm{~m}$; thereafter dilutions increase gradually till they become comparable at the downwind edge of the building. At $h_{s}=5 \mathrm{~m}$, ADMS predicts higher dilutions than those measured in the wind tunnel but their difference decreases with increasing distance from 
the stack. The results show that in general ASHRAE predicts very low dilutions in comparison with the wind tunnel yielding conservative results. This suggests a need to reassess its formulations.

\subsection{Further discussion}

Increasing the stack height reduces rooftop concentrations, particularly in the case of lower exhaust speeds such as $\mathrm{M}<1$ [2]. The results of the present study show that ASHRAE 2007 predicts very low dilutions for all cases. The range of normalised dilutions is approximately from 0.001 to 1 , which corresponds to higher pollutant concentrations at each point compared to wind tunnel results. This would require increased stack velocities to reduce the problem but this may not be necessary. In the present study the stack exhaust velocities were limited to $27 \mathrm{~m} / \mathrm{s}$ (for $\mathrm{M}=5$ ). ASHRAE 2007 states that exhaust speeds between 15 and $20 \mathrm{~m} / \mathrm{s}$ could be a great source of vibration and noise to the occupants of the building [8].

One of the major reasons for the discrepancy between ASHRAE, ADMS and wind tunnel is that the dilution equations in the models do not incorporate the effects of building size / dimensions, stack generated turbulence and other local features, since for a flat roof, turbulence within the recirculation length is mostly governed by the building. In the presence of an RTS there is added turbulence, which restricts plume spread (note that the plume rise equation of ASHRAE (equation 6) does not incorporate this effect). A careful examination of equations 8 and 12 (from ASHRAE 2007 and 2003) and equation 14 (to assess plume concentrations using ADMS), will show that ASHRAE generally considers the height of the plume and adjusts it based on the recirculation lengths of the building (this gets reflected in the exponential terms used in ASHRAE). However, ADMS considers the atmospheric boundary layer height $\left(\mathrm{h}^{*}\right.$ in exponential term of equation 14) without considering the building dimensions, while the dimensions of the plume are only based on the Monin-Obukhov stability criteria. Therefore, ADMS generally assumes greater plume spread within the atmospheric boundary layer thereby

predicting lower concentrations (higher dilutions), which is a general trend in ADMS especially within the first 10-15 m downwind of stack. On the other hand, ASHRAE limits the plume rise within close proximity to the stack based on the dimensions of 
recirculation zone, which is again estimated from building dimensions based on Wilson's study [11] formulation. A major drawback of ASHRAE is that by not considering the turbulence generated by the building/stack/RTS, which alters the dilution depending on the location of the stack or RTS on the building roof, it yields generally higher concentrations than the wind tunnel due to low plume spread predicted. This is conservative but may penalize the design unnecessarily. Therefore, it is suggested that ASHRAE and ADMS may consider including these effects in their formulations and perform proper validation studies with wind tunnel measurements.

\section{Conclusions}

The paper demonstrates the application of ADMS, ASHRAE 2007 and 2003 for the dispersion of building exhaust pollutants in the built environment and compares normalised dilutions with wind tunnel measurements for four specific cases. The results show that the application of ADMS may be problematic for most cases. Additionally, ADMS is not capable of modelling the effect of RTS.

ASHRAE 2007 predicts lower dilutions than wind tunnel data for all cases, while ASHRAE 2003 predicts comparable dilutions to wind tunnel data only for some cases. In general, ASHRAE formulations could improve by incorporating building, RTS and stack generated turbulence effects to estimate plume dilutions on rooftop.

\section{Acknowledgements}

The authors are thankful to the Institut de recherche Robert-Sauvé en santé et en sécurité du travail (IRSST) for funding this research.

\section{References}

[1] Carruthers D, Riddle A, Sharpe A, McHugh C, Stocker J. Comparison between FLUENT and ADMS for atmospheric dispersion modelling. Atmospheric Environment, 2004; 38: 1029-1038.

[2] Schulman L, Scire J S. Building downwash screening modelling for the downwind circulation cavity. Journal of the Air Waste Management Association, 1993; 43: 11221127. 
[3] Gifford F A. Use of routine meteorological observation for estimating atmospheric dispersion, Nuclear Safety, 1961; 2: 47-51.

[4] Pasquill F. The estimation of the dispersion of wind borne material. Meteorological Magazine, 1961; 90: 33-39.

[5] Kesarkar A, Dalvi M, Kaginalkar A, Ojha A. Coupling of the weather research and forecasting model with AERMOD for pollutant dispersion modelling. A case study for PM10 dispersion over Pune, India. Atmospheric Environment, 2007; 41: 1976-1988.

[6] Stathopoulos T, Bahloul A, Hajra B. Analytical evaluation of dispersion of exhaust from rooftop stacks on buildings. IRSST research report R-576, Institut de recherche Robert-Sauvé en santé et en sécurité du travail, Montreal, Canada, 2008.

[7] ASHRAE. Building Air Intake and Exhaust Design. ASHRAE Applications Handbook, Chapter 44, American Society of Heating, Refrigerating and Air-Conditioning Engineering Inc., Atlanta, USA, 2003.

[8] ASHRAE. Building Air Intake and Exhaust Design. ASHRAE Applications Handbook, Chapter 44, American Society of Heating, Refrigerating and Air-Conditioning Engineering Inc., Atlanta, USA, 2007.

[9] Briggs G A. Plume rise and buoyancy effects in atmospheric sciences and power production. D. Randerson, ed. US Department of Energy DOE/TIC-27601 (DE 84005177), Washington, DC, USA, 1984.

[10] Wilson D J, Fabris I, Ackerman M Y. Measuring adjacent effects on laboratory exhaust stack design. ASHRAE Transactions, 1998; 88 (1): 513-533.

[11] Wilson D J. Flow patterns over flat roofed buildings and application to exhaust stack design. ASHRAE Transactions, 1979; 85: 284-295.

[12] Wilson D J, Britter B E. Estimation of building surface concentrations from nearby point sources. Atmospheric Environment, 1982; 28: 2631-2646.

[13] ADMS 3 User Guide, Cambridge Environmental Research consultants Limited, Cambridge, UK, 2004.

[14] Snyder W H. Guidelines for fluid modelling of atmospheric diffusion. EPA office of Air quality, planning and standards, Research Triangle Park, USA, EPA-600/8-81-009, 1981.

[15] Flow components and control equipment brochure, Matheson Tri-Gas, USA, 2007. 
[16] ASHRAE. Airflow around Buildings. ASHRAE Applications Handbook, Chapter 24, American Society of Heating, Refrigerating and Air-Conditioning Engineers Inc., Atlanta, USA, 2009.

[17] Stathopoulos T, Lazure L, Saathoff P. Tracer gas investigation of reingestion of building exhaust in an urban environment. IRSST research report R-213, Institut de recherche Robert-Sauvé en santé et en sécurité du travail, Montreal, Canada, 1999.

[18] Schulman and Scire. Effect of stack height, exhaust speed, and wind direction on concentrations from a rooftop stack. ASHRAE Transactions, 1991; 77; 573-585

[19] Lowery KP, Jacko RB. A wind tunnel study into the effects of raised intakes and parapets on fresh air intake contamination by a rooftop stack. Journal of the Air and Waste Management Association, 1996; 46: 847-852.

[20] Carruthers D, Mckeown A M, Hall D J, Porter S. Validation of ADMS against wind tunnel data of dispersion from chemical warehouse fires. Atmospheric Environment, 1999; 33: 1937-1953.

[21] Turner D B. Workbook of atmospheric dispersion estimates: An introduction to dispersion modelling. Second edition, CRC press, USA, 1994. 


\section{Appendix}

For the low-rise building considered in this study (refer to Figure 5 (b)), the receptor lying $5 \mathrm{~m}$ downwind of the stack at $\theta=0^{\circ}$ has been chosen. Table 4 presents a summary of the calculations, which are common to both ASHRAE versions.

Table 4. Summary of calculations following ASHRAE 2003 and ASHRAE 2007 for

Figure 9 (b).

\begin{tabular}{|l|l|l|}
\hline Parameter & Value used & Remark \\
\hline $\mathrm{h}_{\mathrm{s}}$ & $1 \mathrm{~m}$ & Chosen value of stack height pertaining to Figure $9(\mathrm{~b})$ \\
\hline $\mathrm{d}_{\mathrm{e}}$ & $0.6 \mathrm{~m}$ & Stack diameter \\
\hline $\mathrm{M}$ & 5 & Exhaust momentum $\left(\mathrm{V}_{\mathrm{e}} / \mathrm{U}_{\mathrm{H}}\right)$. See Figure $9(\mathrm{~b})$ \\
\hline $\mathrm{U}_{\mathrm{H}}$ & $5.4 \mathrm{~m} / \mathrm{s}$ & Wind speed at building height $\mathrm{H}$, where $\mathrm{H}=15 \mathrm{~m}$ \\
\hline $\mathrm{V}_{\mathrm{e}}$ & $27 \mathrm{~m} / \mathrm{s}$ & Exhaust velocity \\
\hline $\mathrm{t}_{\text {avg }}$ & $2 \mathrm{minutes}$ & Recommended by ASHRAE 2007 \\
\hline$\beta$ & 1 & Value for an uncapped stack \\
\hline$\sigma_{\mathrm{o}} / \mathrm{d}_{\mathrm{e}}$ & 4.86 & Value obtained from equation 11 \\
\hline$\sigma_{\mathrm{y}} / \mathrm{d}_{\mathrm{e}}$ & 5.45 & Value obtained from equation 9 \\
\hline$\sigma_{\mathrm{z}} / \mathrm{d}_{\mathrm{e}}$ & 5.45 & Value obtained from equation 10 \\
\hline $\mathrm{h}$ & $10 \mathrm{~m}$ & Value obtained from equation 5 \\
\hline $\mathrm{h}_{\mathrm{r}}$ & $9 \mathrm{~m}$ & Value obtained from equation 6 \\
\hline $\mathrm{h}_{\mathrm{d}}$ & $0 \mathrm{~m}$ & Value obtained from equation 7 \\
\hline $\mathrm{R}$ & $22.31 \mathrm{~m}$ & Building scaling length from equation 1 \\
\hline $\mathrm{X}_{\mathrm{c}}$ & $11.16 \mathrm{~m}$ & Location of recirculation length from equation 3 \\
\hline $\mathrm{h}_{\text {Top }}$ & $5 \mathrm{~m}$ & Height of recirculation zone from equation 2 \\
\hline $\mathrm{L}_{\mathrm{c}}$ & $20 \mathrm{~m}$ & Length of recirculation zone from equation 4 \\
\hline $\mathrm{Q}$ & $7.63 \mathrm{~m} / \mathrm{s}$ & discharge rate of effluents from stack $\left(\pi \mathrm{x} 0.25 \mathrm{x} 0.6^{2} \mathrm{x} \mathrm{V}_{\mathrm{e}}\right)$ \\
\hline
\end{tabular}

\section{ASHRAE 2007}

ASHRAE 2007 defines a term called " $\zeta$ ", which is the vertical separation between plume rise $(\mathrm{h})$ and $\mathrm{h}_{\mathrm{Top}}$

$\zeta=\mathrm{h}-\mathrm{h}_{\mathrm{Top}}=5 \mathrm{~m}$

$\mathrm{D}_{\mathrm{r}}=76.48$ (from equation 8 ) 
$D_{\text {normalised }}=0.49($ from equation 13) - see value in Figure $9(b)$.

\section{ASHRAE 2003}

ASHRAE 2003 estimates the effective plume height (h) from equation 5. In this case $\mathrm{h}=10 \mathrm{~m}$

$\mathrm{D}_{\mathrm{r}}=2551$ (from equation 12)

$D_{\text {normalised }}=16.01($ from equation 13$)-$ see value in Figure $9(b)$.

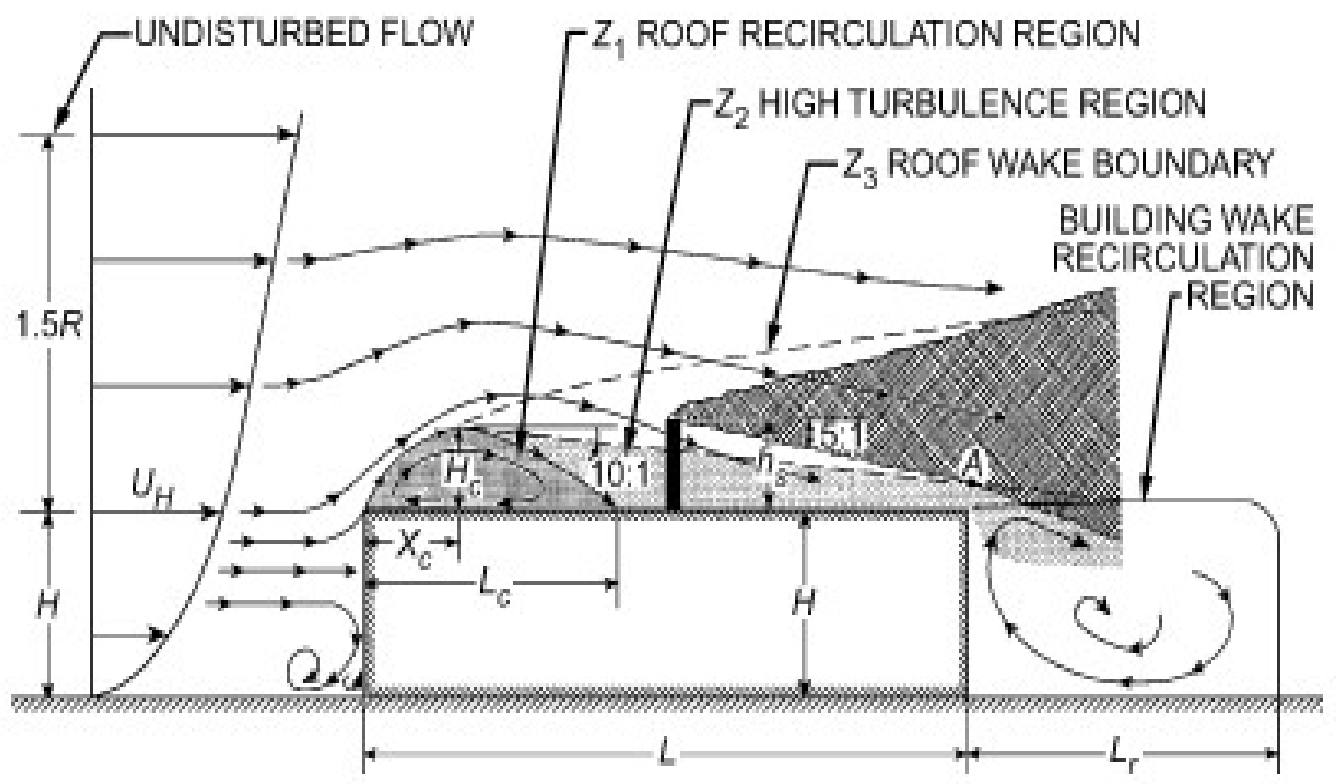

Figure 1 Design procedure for required stack height to avoid contamination (from Wilson. [11]) 


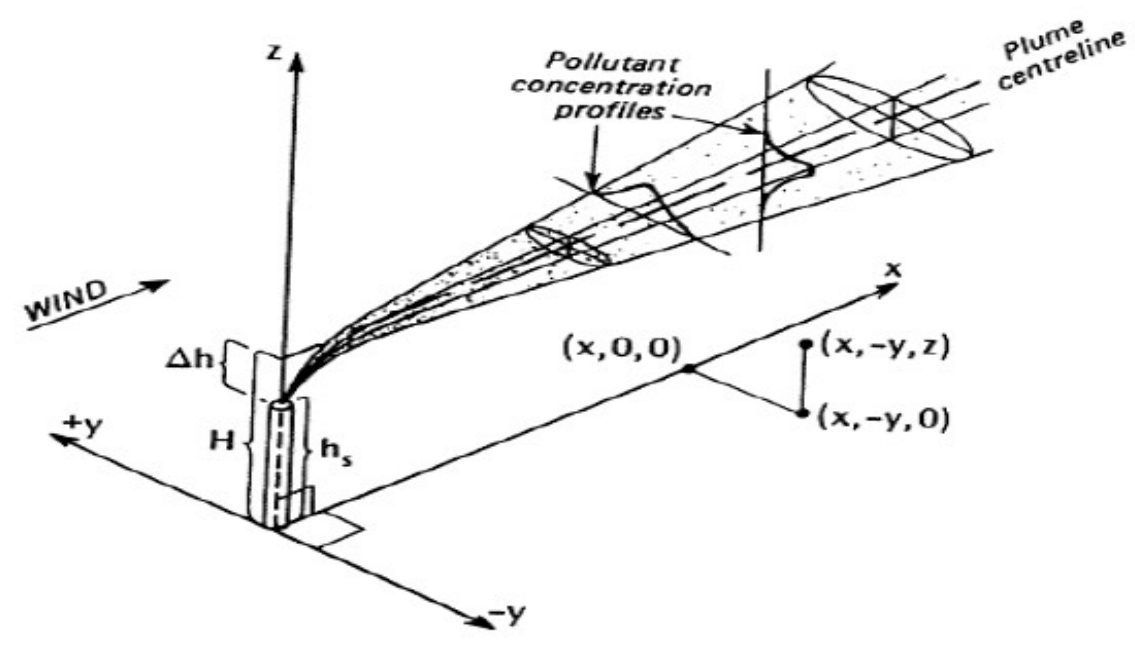

Figure 2 Coordinate system showing Gaussian distributions (from Turner. [21])
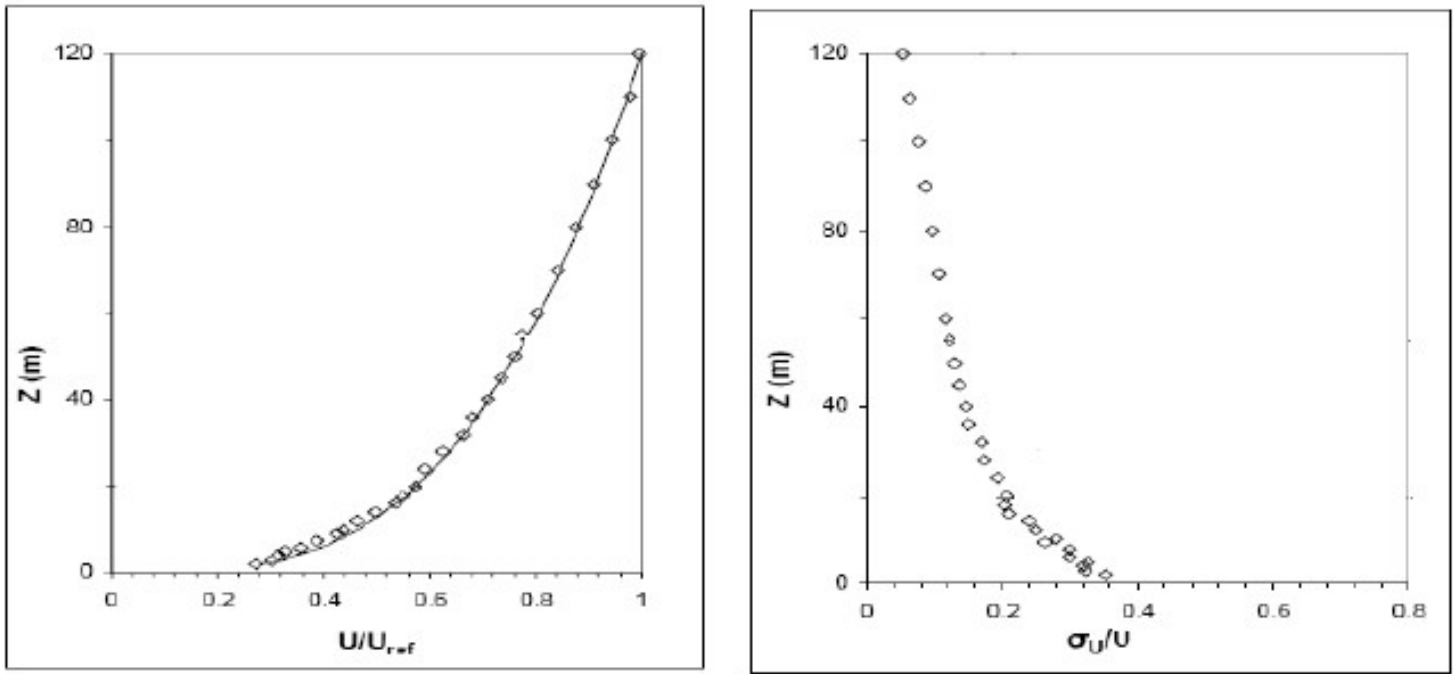

Figure 3 Mean velocity and turbulence intensity profiles measured at the Boundary Layer Wind tunnel of Concordia University. 


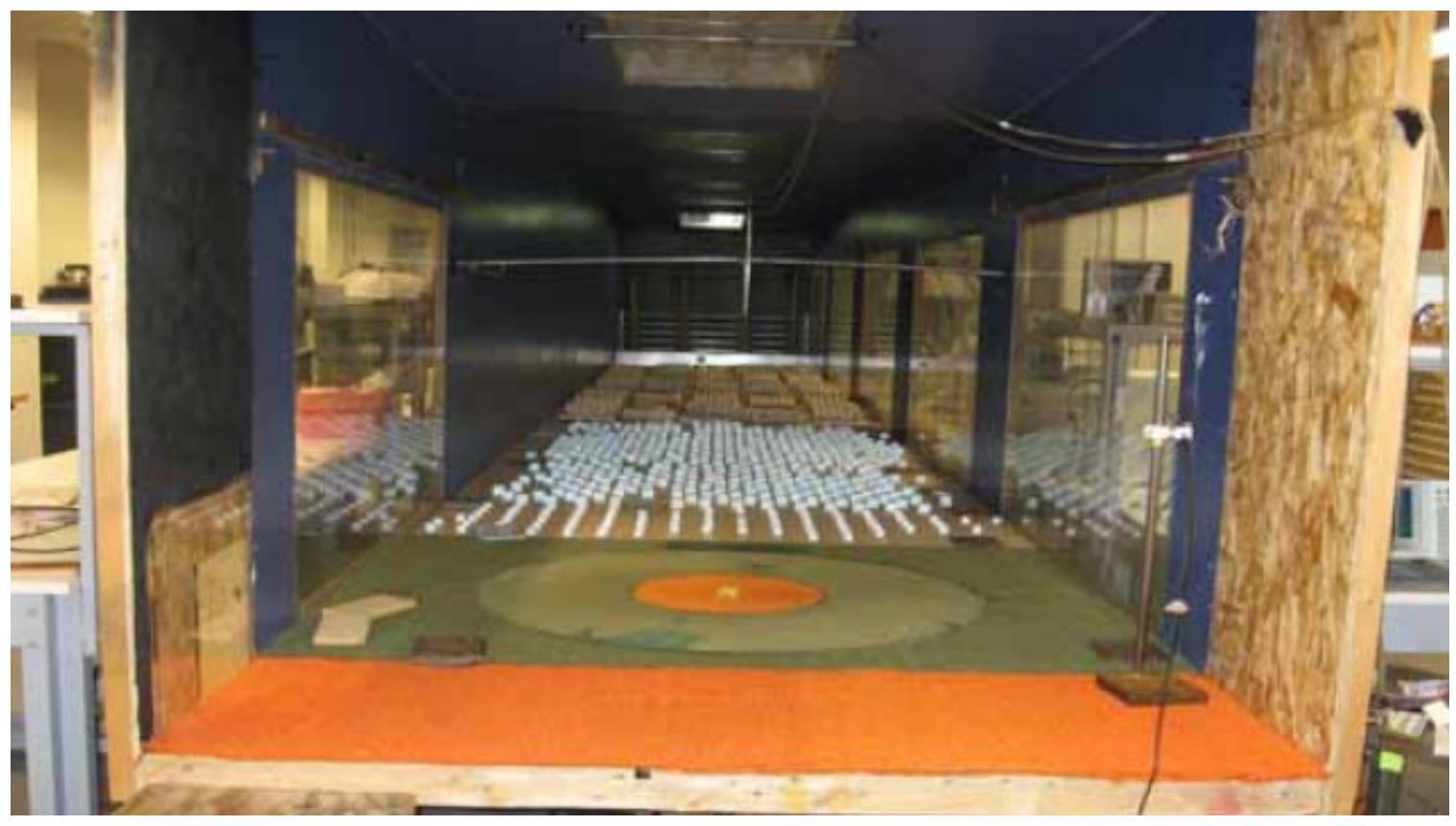

Figure 4 Front view section of the Boundary Layer Wind tunnel at Concordia University (from Stathopoulos et al. [6]). 
Figure 5(a)

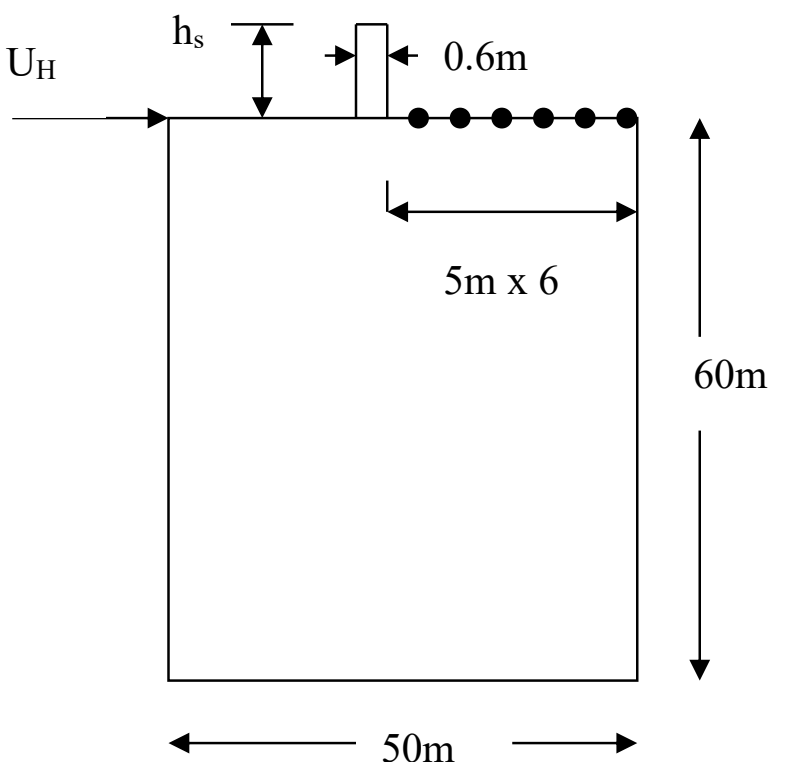

$\underline{\text { Elevation }}$

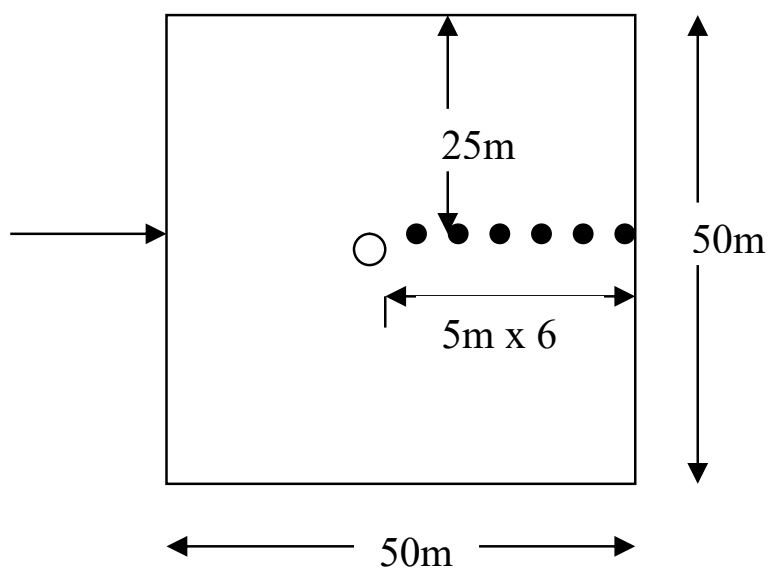

$\underline{\text { Plan }}$ $\underline{\text { Figure 5(b) }}$

- denotes receptor location

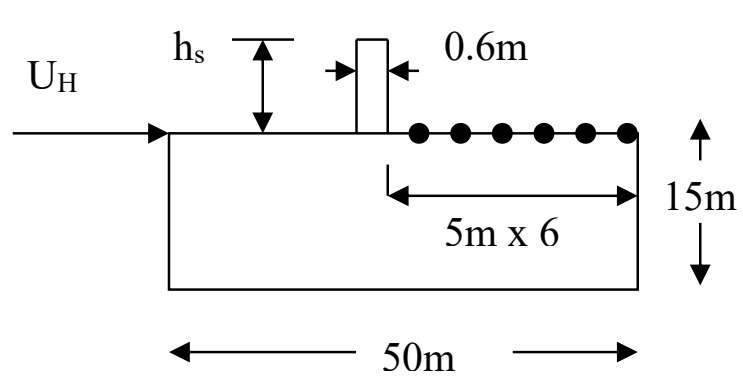

$\underline{\text { Elevation }}$

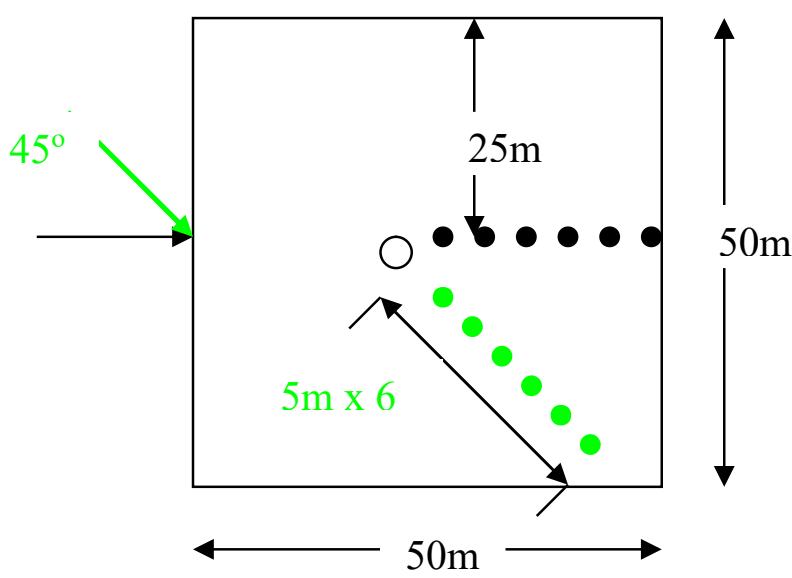

$\underline{\text { Plan }}$

Figure 5 Stack and receptor locations for, a) high-rise building with $\theta=0^{\circ}$; b) low-rise with $\theta=$ $0^{\circ}$ and $45^{\circ}$ 


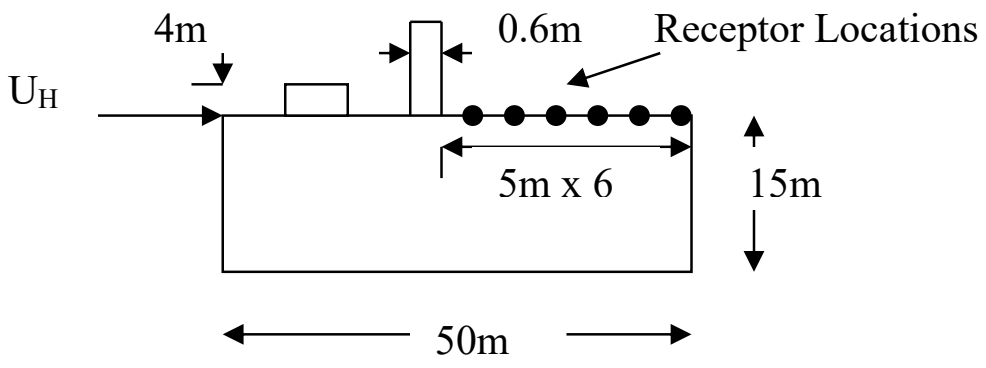

\section{Elevation}

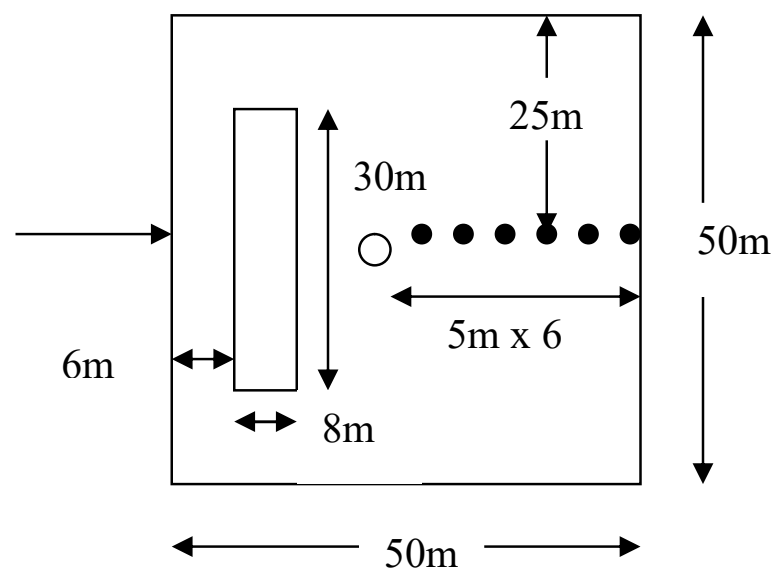

$\underline{\text { Plan }}$

Figure 6 Low-rise building with RTS with stack and receptor locations; $\theta=0^{\circ}$

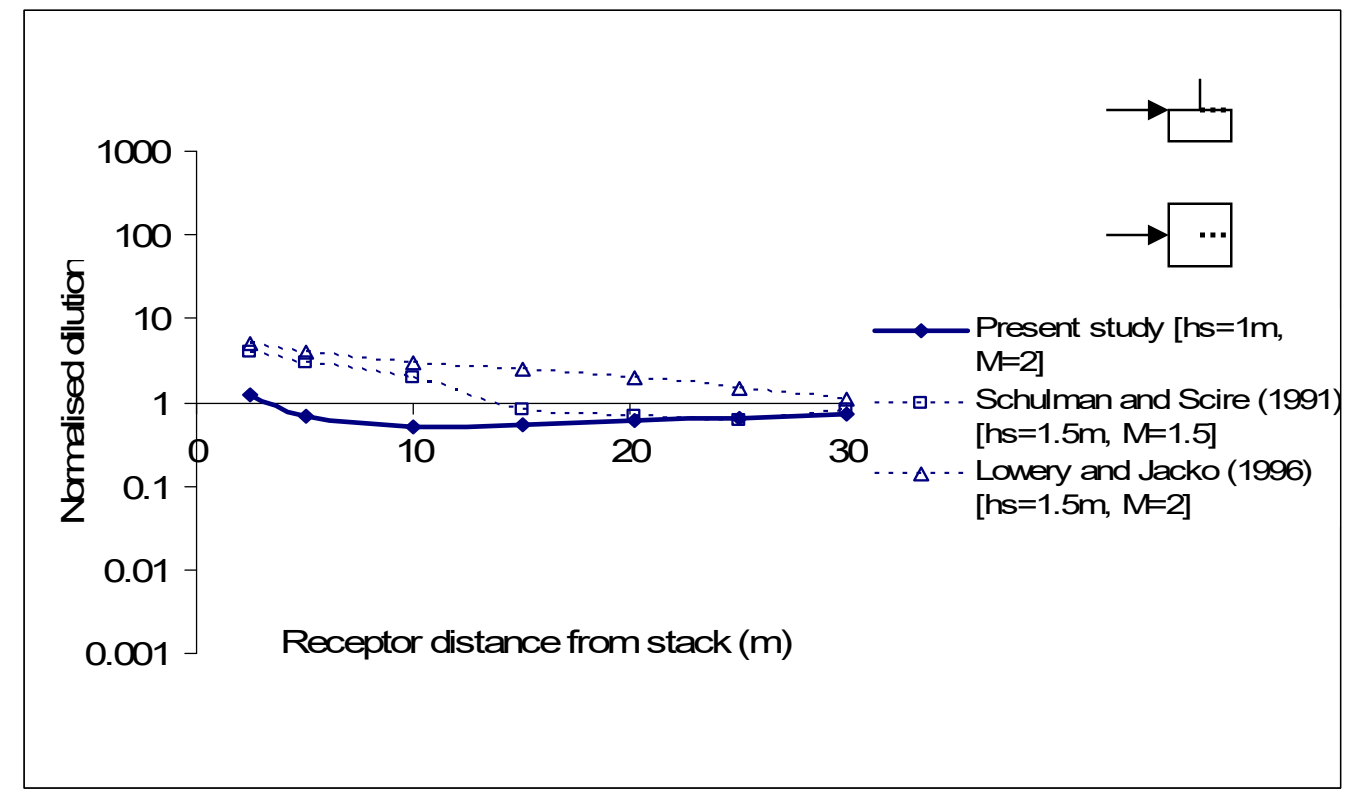

Figure 7. Comparison of wind tunnel measured dilutions and those from previous studies 


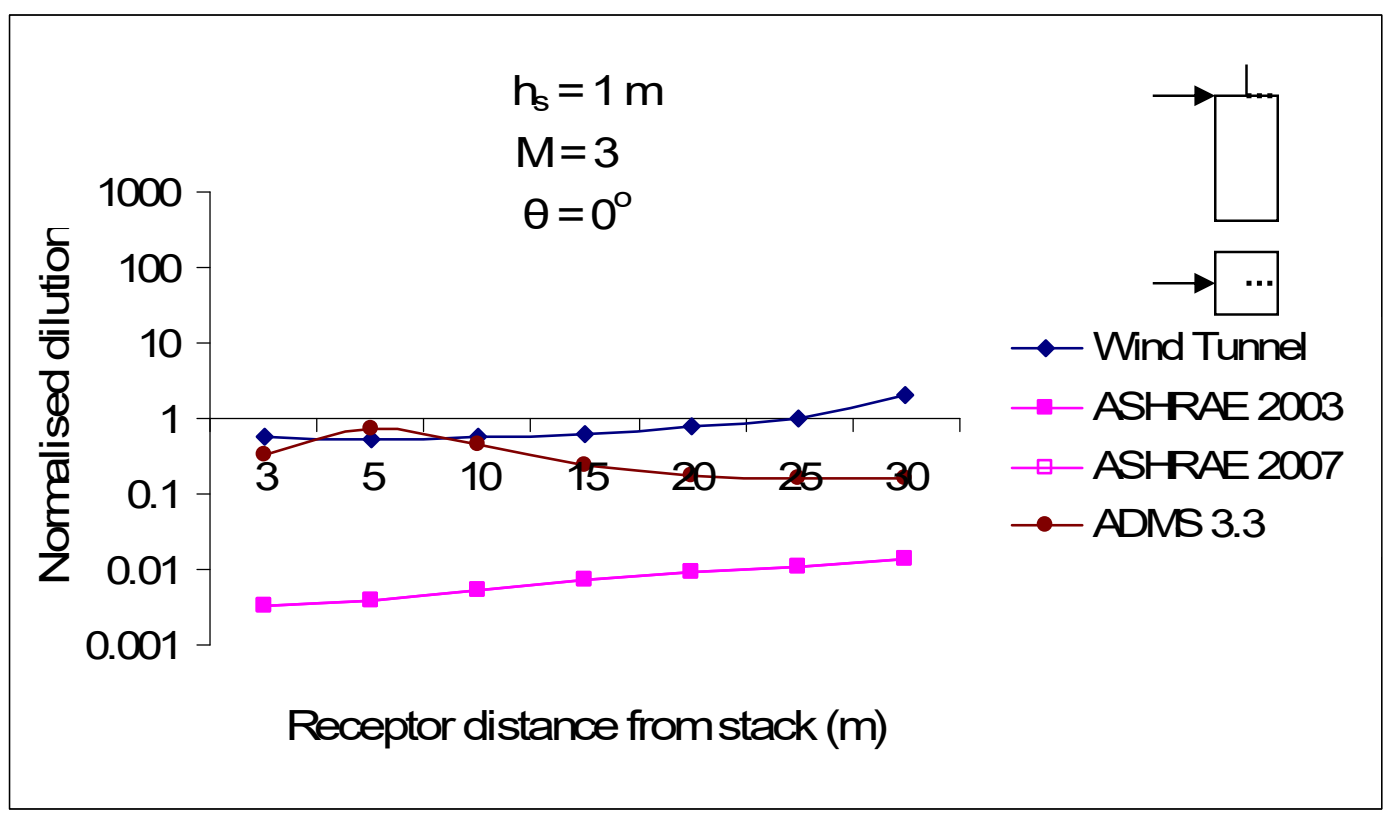

a)

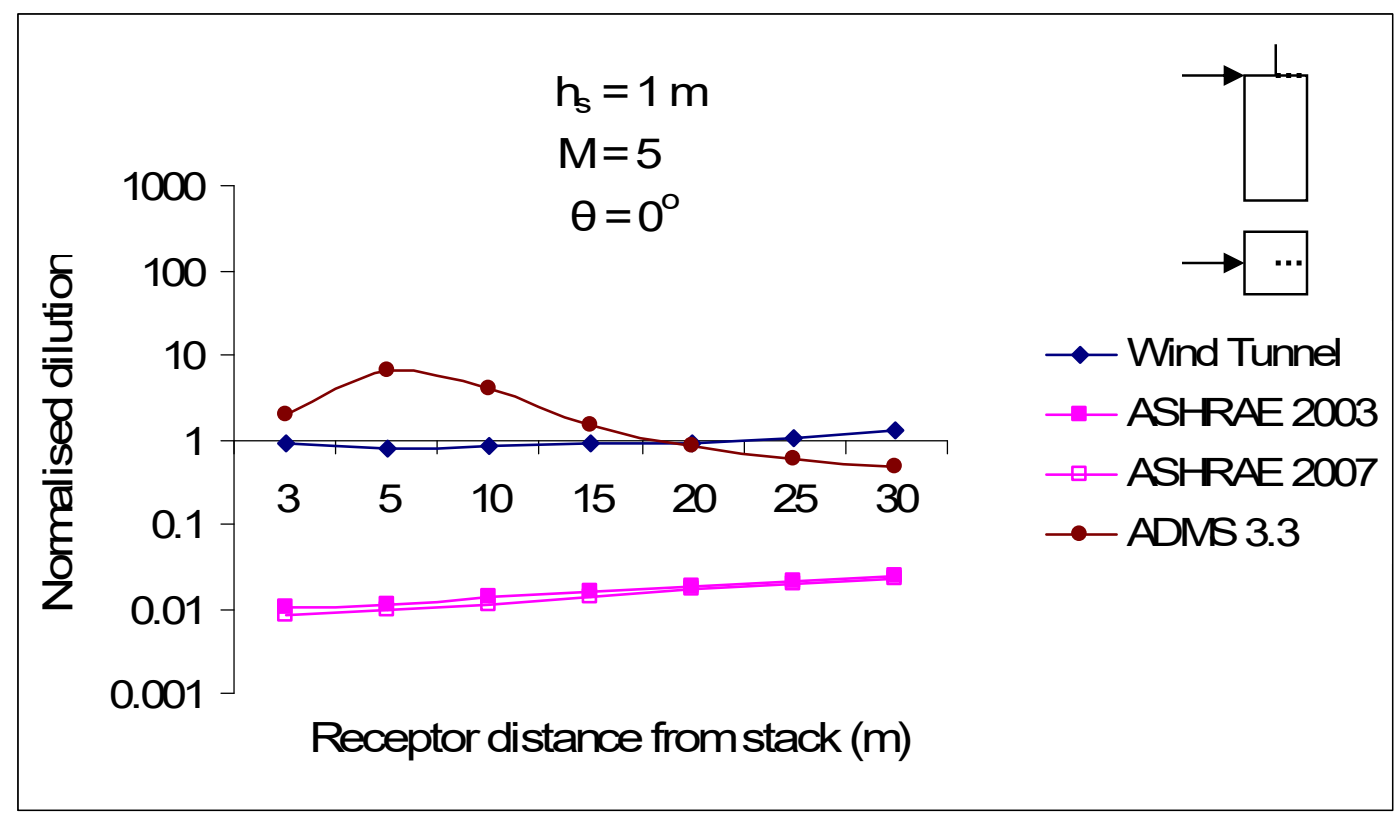

b)

Figure 8 Normalised dilution at downwind receptors for high-rise building; $\theta=0^{\circ} \mathrm{h}_{\mathrm{s}}=1 \mathrm{~m}$, a) $\mathrm{M}=3$; b) $\mathrm{M}=5$ 


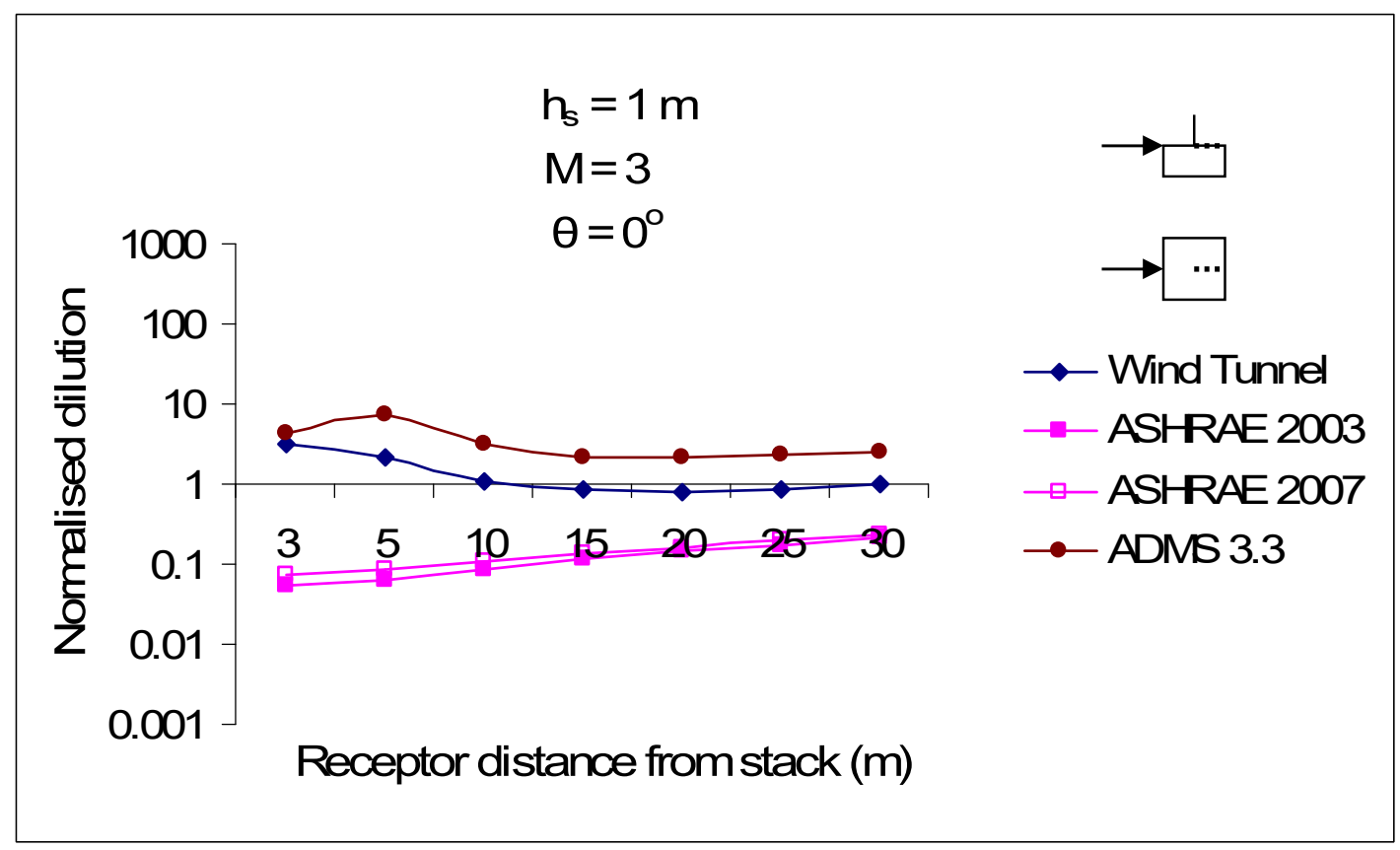

a)

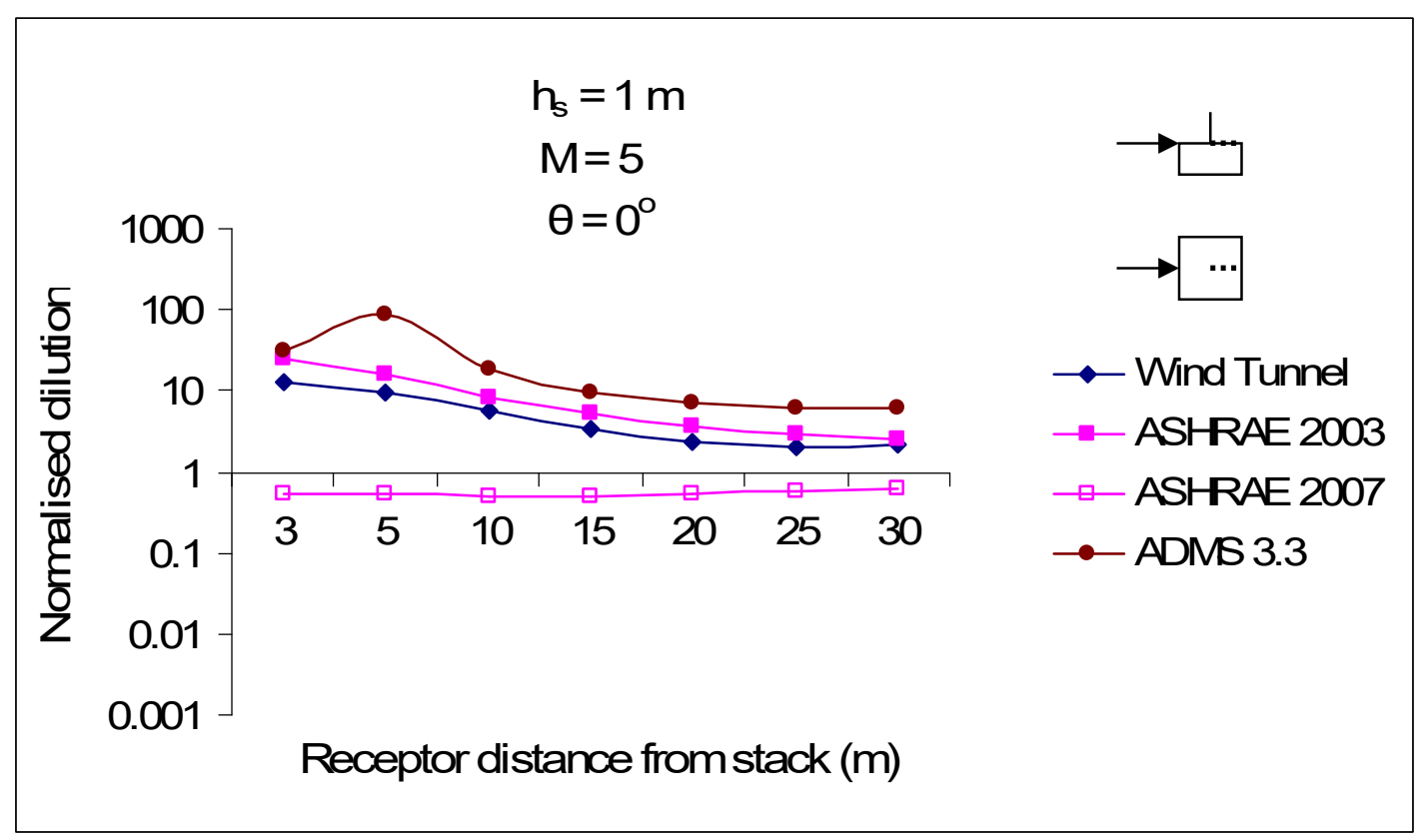

b)

Figure 9 Normalised dilution at downwind receptors for low-rise building; $\theta=0^{\circ} \mathrm{h}_{\mathrm{s}}=$ $1 \mathrm{~m}$, a) $\mathrm{M}=3$; b) $\mathrm{M}=5$ 


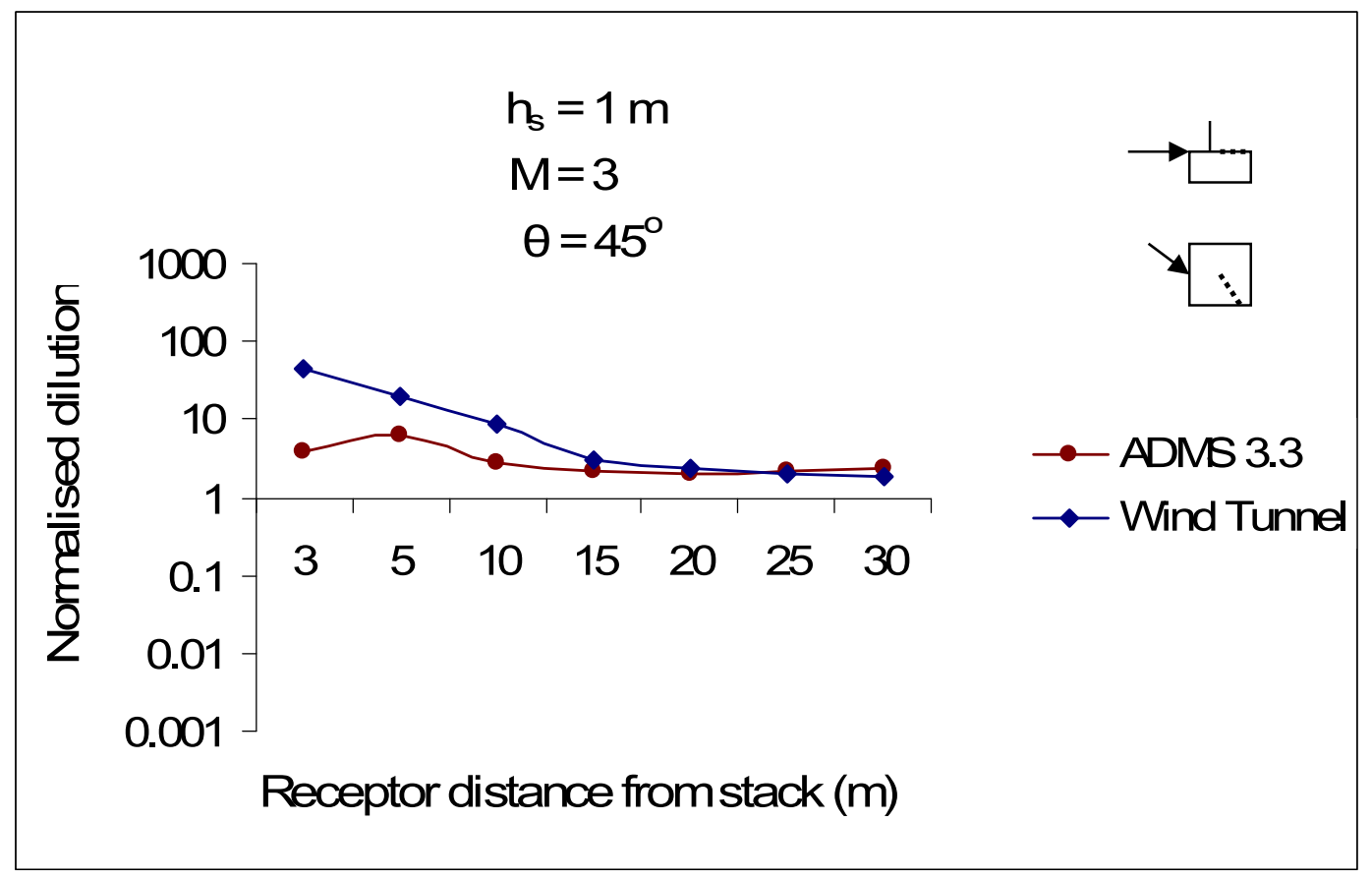

a)

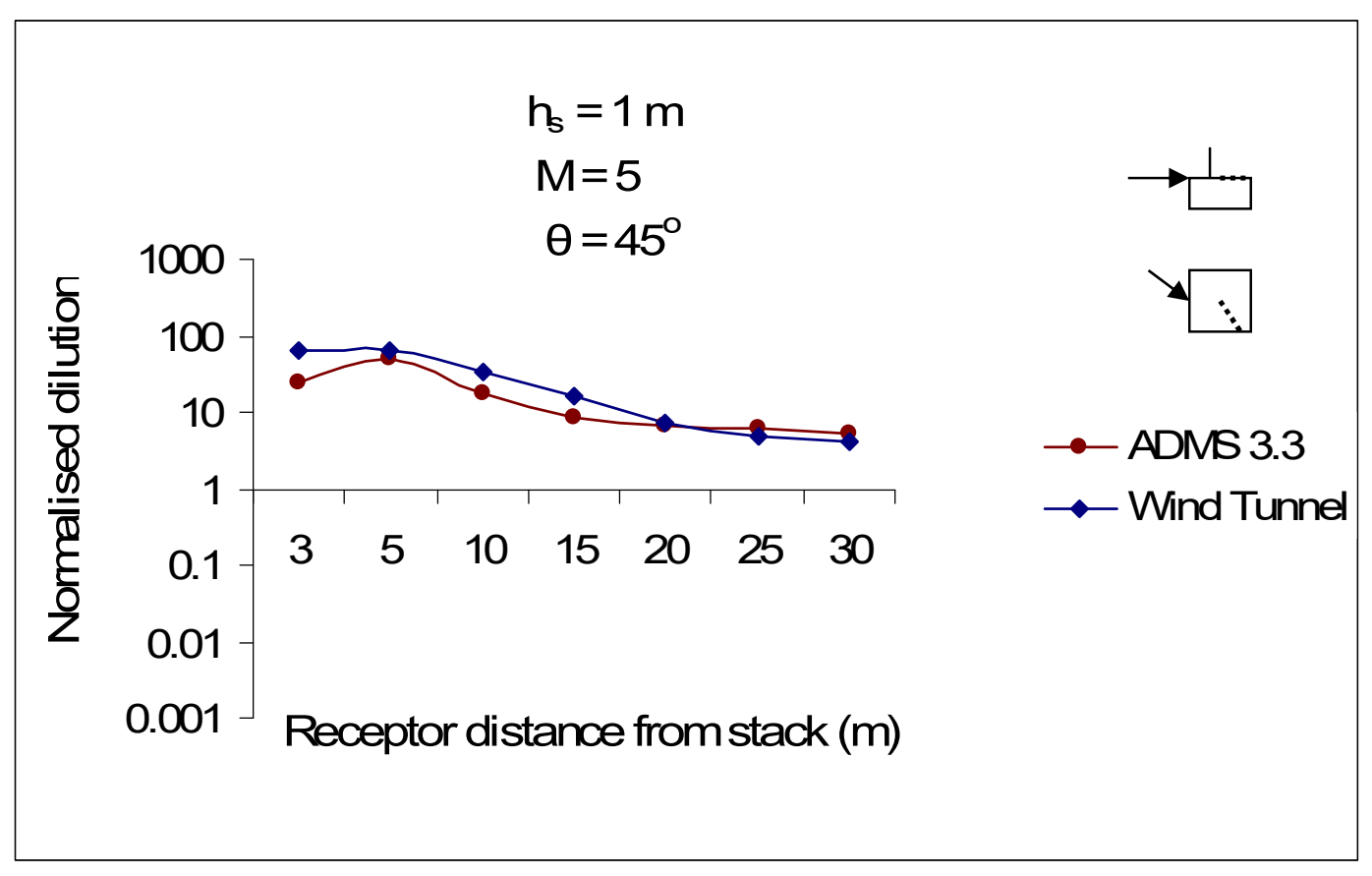

b)

Figure 10 Normalised dilution at downwind receptors for low-rise building; $\theta=45^{\circ} \mathrm{h}_{\mathrm{s}}=1$ m, a) $M=3$; b) $M=5$ 


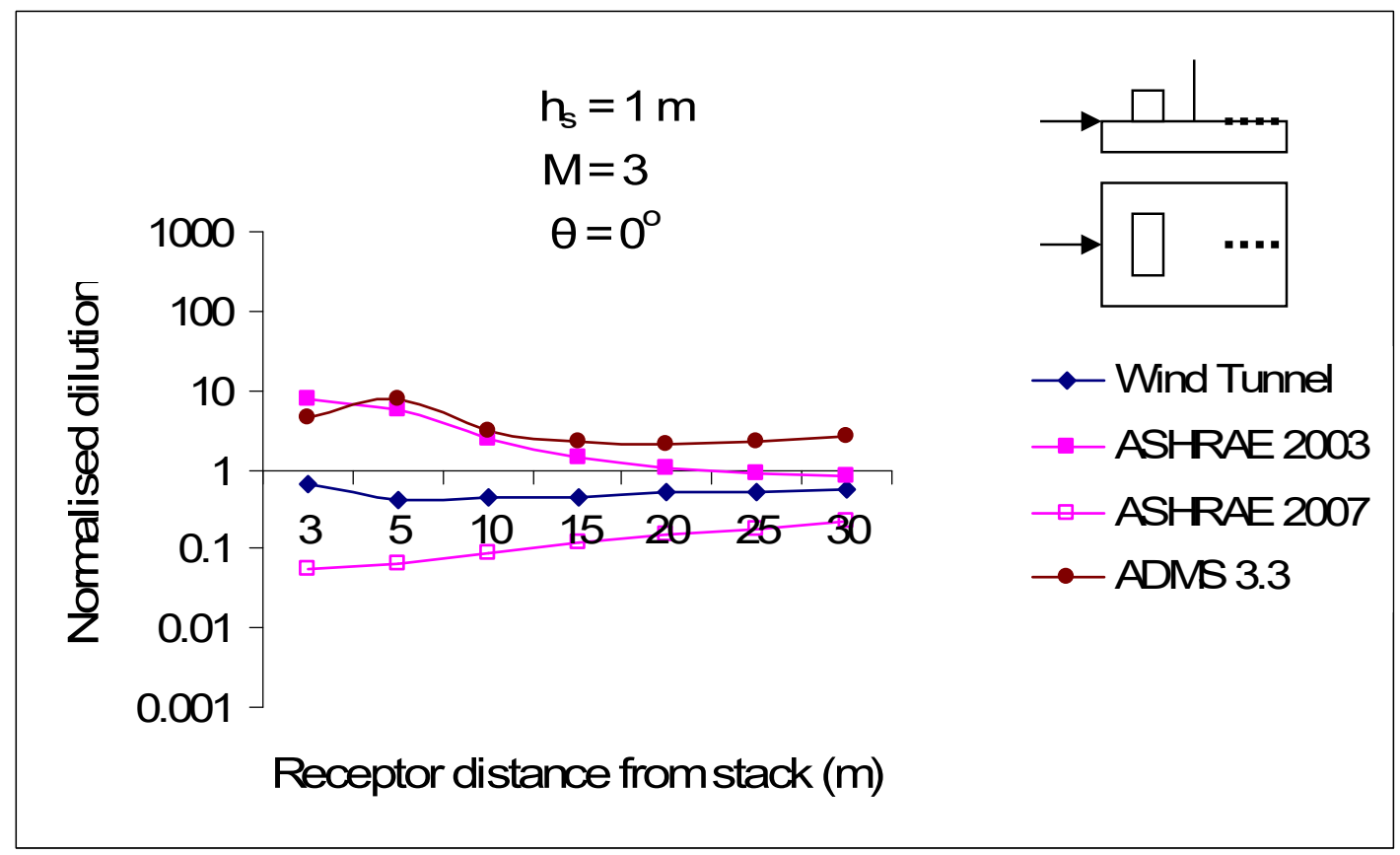

a)

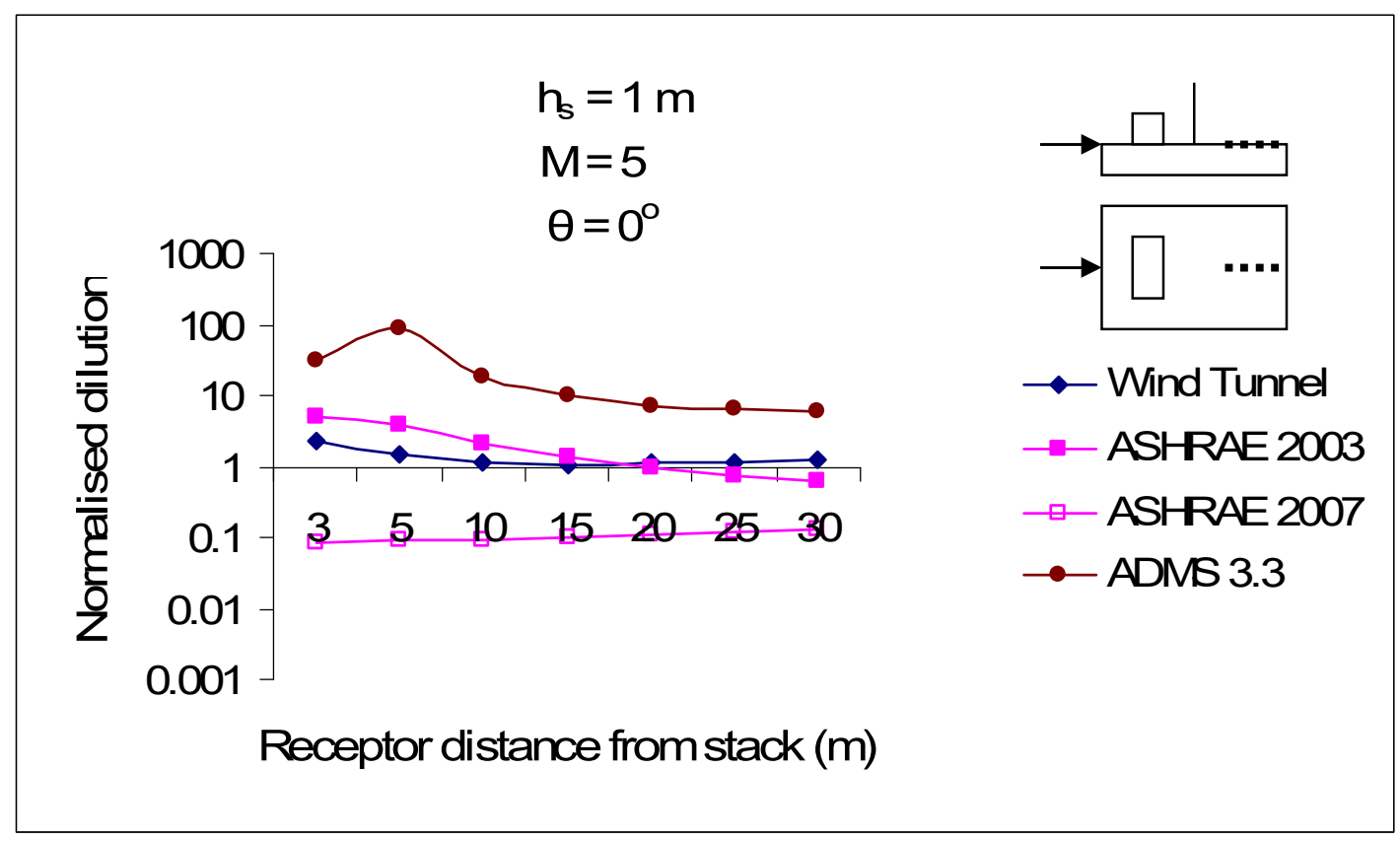

b)

Figure 11 Normalised dilution at downwind receptors for low-rise building with RTS; $\theta=$ $0^{\circ} h_{s}=1 \mathrm{~m}$, a) $M=3$; b) $M=5$ 


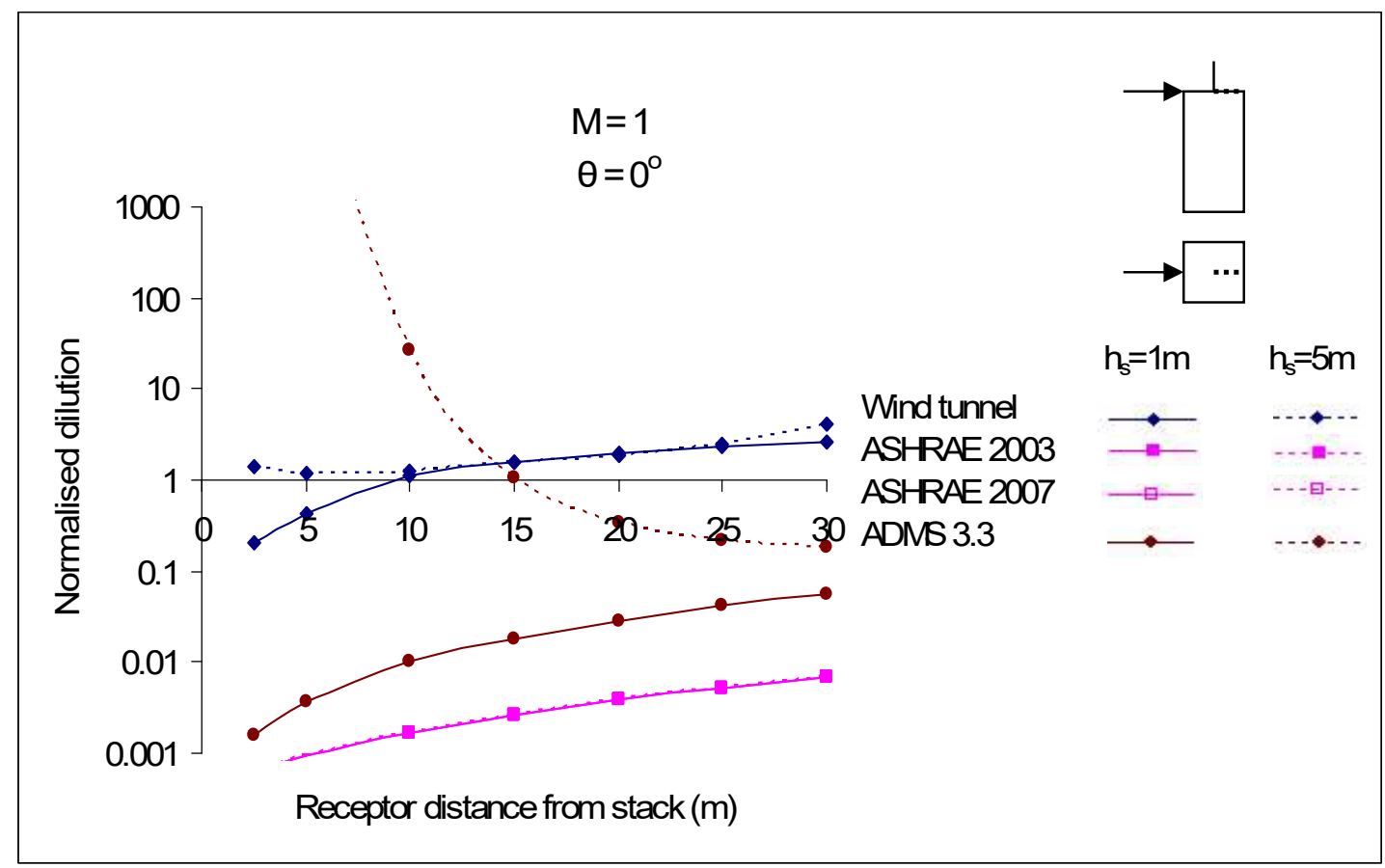

a)

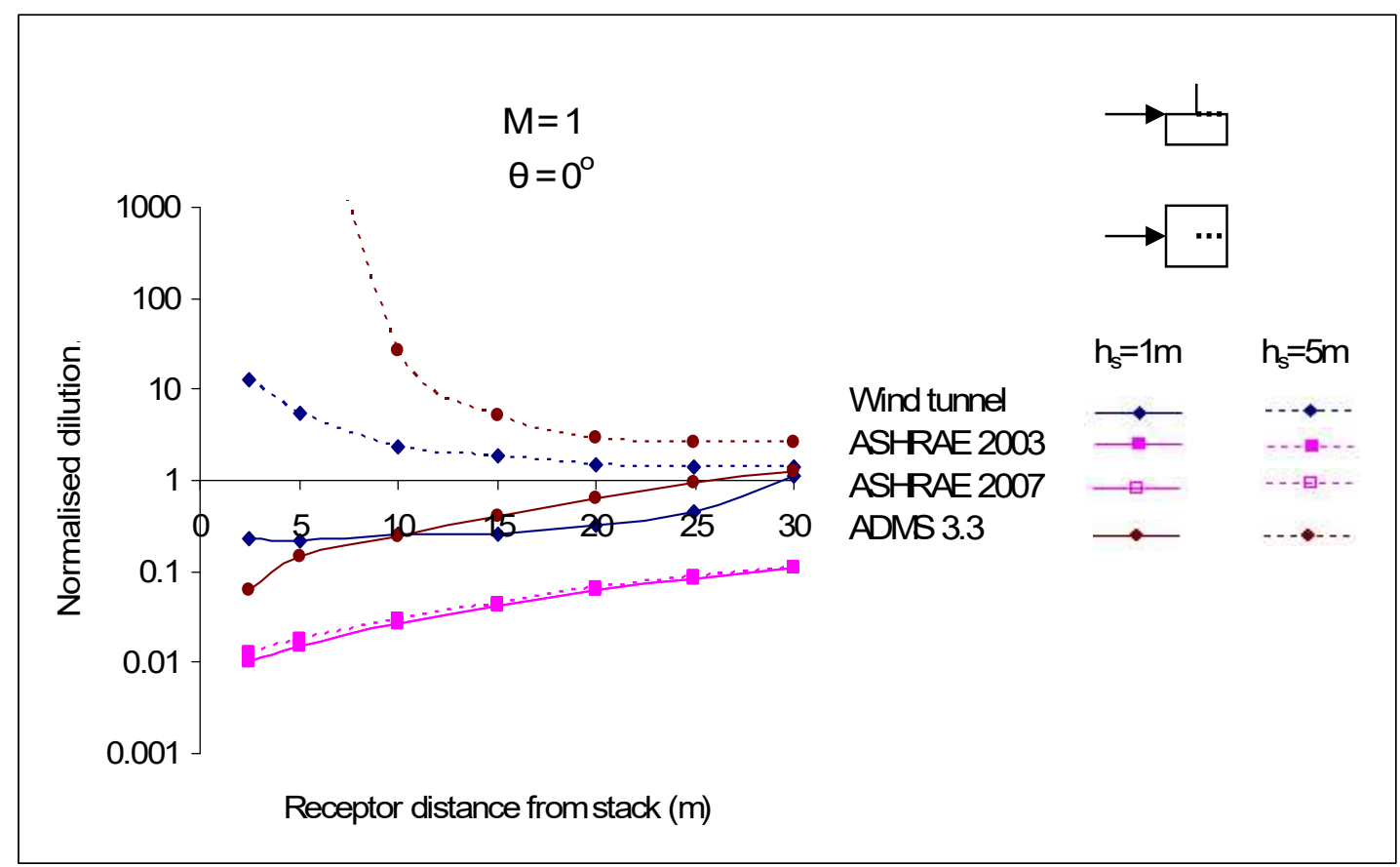

b)

Figure 12 Normalised dilution at downwind receptors at $\mathrm{M}=1$ for a) high-rise building; $\mathrm{b}$ ) low-rise building 